\title{
Yabancı Uyruklu Öğrencilerin Bulunduğu İlkokullarda İstenmeyen Öğrenci Davranışlarının Nicel Açıdan İncelenmesi ${ }^{*}$
}

\author{
Adnan DELEN \\ Öğretmen, Milli Eğitim Bakanlığı, \\ Midyat İstiklal İlkokulu, Mardin \\ adnandelen_tb@hotmail.com \\ Orcid ID: https://orcid.org/0000-0001-9036-1501 \\ Muhammet Hanifi ERCOŞKUN \\ Dr. Öğr. Üyesi, Atatürk Üniversitesi, \\ Kazım Karabekir Eğitim Fakültesi \\ ercoskun@atauni.edu.tr \\ Orcid ID: https://orcid.org/0000-0001-9932-3659
}

Öz

Türk öğrencilerle beraber eğitim görmeye başlayan ve bir kısmı halen konaklama tesisinde eğitim gören yabancı uyruklu öğrencilerin birbirleriyle, Türk öğrencilerle ve öğretmenleriyle olan davranış ilişkilerini ve istenmeyen davranışlarını incelemek önemlidir. Bu araştırma, mülteci öğrencilerin devam ettikleri sınıflarda ortaya çıkan istenmeyen davranışların gerçekleşme düzeylerini öğretmenlerin cinsiyeti, sınıfta bulunan mülteci öğrenci sayısı ve öğretmenlerin konuşabildikleri yabancı diller değişkenleri açısından incelemek amacıyla yapılmıştır. Araştırmanın bulguları incelendiğinde, yabancı uyruklu öğrencilerin geldikleri ülkelerde kendi kültürlerine göre normal olan davranışları (sınıfta bir şeyler yemek, sırasında düzgün oturmamak, ders araç-gereçlerini düzgün kullanmamak...vb) halen devam ettirdikleri görülmüştür. Yabancı uyruklu öğrencilerin dil ve iletişim problemlerinden dolayı ders dışı şeylerle ilgilendikleri ve ödevlerini istenildiği şekilde yapmadıkları görülmüştür. Yabancı uyruklu öğrencilerin istenmeyen davranış sergileme nedenlerinin; toplumsal ve kültürel

${ }^{1}$ Makale Geliş/Kabul Tarihi: 20.11.2019 / 15.10.2020

* $\mathrm{Bu}$ çalışma, ilk yazarın "Yabancı Uyruklu Öğrencilerin Bulunduğu İlkokullarda İstenmeyen Öğrenci Davranışlarının İncelenmesi” başlıklı yüksek lisans tezinin bir kısmından özetlenerek hazırlanmıştır

ve 18-22 Nisan 2018 tarihinde Antalya'da düzenlenen 27. Uluslararası Eğitim Bilimleri Kongresi'nde özet bildiri olarak sunulan bildirinin genişletilmiş halidir.

Künye Bilgisi: Delen, A. ve Ercoşkun, M.H. (2020). Yabancı Uyruklu Öğrencilerin Bulunduğu İlkokullarda İstenmeyen Öğrenci Davranışlarının Nicel Açıdan Incelenmesi. Kahramanmaraş Sütçü Imam Üniversitesi Sosyal Bilimler Dergisi, 17 (2), 572-599. DOI: 10.33437/ksusbd.649281 


\title{
A. Delen-M.H. Ercoskun $\quad$ Yabancı Uyruklu Öğrencilerin Bulunduğu...
}

değişim, dil ve iletişim problemleri, ekonomik sıkıntılar ve ailevi nedenler olduğu görülmüștür. Bu nedenlere bağlı olarak yabancı uyruklu öğrencilerin sınıf ve okul ortamında istenmeyen davranışlara yöneldikleri düşünülmektedir.

Anahtar Kelimeler: Geçici eğitim merkezi (GEM), Yabancı Uyruklu Öğrenci, Mülteci Öğrenci, İstenmeyen Öğrenci Davranışı.

\section{The Quantitative Investigation of the Undesirable Student Behaviors in the Primary Schools Where There Are Foreign Students}

\begin{abstract}
It is important to examine the behavioral relationships and undesirable behaviors of refugee students, who are starting to study with Turkish students and who are currently studying at the accommodation facility, to each other, with Turkish students and teachers. This study aims to analyze the level of the refugee students' undesirable behaviors in their classrooms in terms of various factors such as teachers' gender, the number of refugee students in the integrated classrooms and the foreign languages that the teachers can speak. When the findings of the research are examined; it has been observed that foreign students still continue their normal behavior according to their own culture in their countries where they come from, such as eating something in class, sitting improperly, and using classroom equipment improperly, etc. It is thought that foreign students are interested in extracurricular things due to their language and communication problems and do not perform their duties as requested. It was observed that the reasons for the undesirable behaviors of the foreign students are social and cultural change, language and communication problems, economic troubles and parental reasons. Depending on these reasons, it can be said that foreign students incline towards undesirable behaviors in the classroom and school environment.
\end{abstract}

Keywords: Temporary Education Center (TEC), Foreign Student, Refugee Student, Undesirable Students Behavior.

\section{GİRIŞ}

Göç; ekonomik, sosyal ve siyasi sebeplerle insanların veya toplumların bir ülkeden başka bir ülkeye, bir yerden başka bir yere gitmeleri veya taşınmaları 
anlamına gelir. Bir ve birkaç bireyden oluşan insan topluluğunun ülkelerarası sınırları geçmesiyle gerçekleşen göç türüne "dış göç", aynı ülke içinde yapılan yer değişikliğine ise "iç göç" denilmektedir (Sağlam, 2006). Ortadoğu'da yaşanan savaştan dolayı 2011 yılından beri, Türkiye'ye, ağılıklı olarak Suriye'den olmak üzere birçok insan göç etmiştir. "Açık Kapı Politikası" uygulayarak dünyada sığınmacılara en çok ev sahipliği yapan Türkiye, savaştan kaçan yabancı uyruklulara uluslararası mülteci hukuku teamüller gereğince "geçici koruma" statüsü vermiştir. Böylece, Türkiye'ye göç eden Suriyelilerin kendi ülkelerine dönene kadar Türkiye'de misafir statüsünde barındırılıp başta eğitim ve sağlı olmak üzere her çeşit ihtiyaçlarının karşılanması kararlaştırılmıştır. Bu bağlamda; çeşitli uluslararası anlaşmaların yanı sıra Türkiye'deki eğitim-öğretimle ilgili temel hukuki düzenlemelerde de çocukların korunması, eğitim ihtiyaçlarının karşılanması ve her çeşit yararlarının gözetilmesine vurgu yapılmaktadır.

Göç edilen ülkede işgücü zayıf ve göç edenler nitelikli işgücüne sahipse olumlu; göç edilen ülkenin kaynakları az ve işsizlik yüksekse olumsuz sonuçlar doğurabilmektedir. Ayrıca göç sonucunda toplumsal, kültürel ve ekonomik manada birçok etkileşim ve değişimler yaşanabilmektedir. Sosyal ve kültürel açıdan etkileşimin en çok olduğu sistemlerden birisi de eğitim sistemleridir. Eğitim sistemlerinin uygulandığ 1 ve gerçekleştirildiği yerler ise okul ve sınıflardır. Sosyal, ekonomik ve kültürel açıdan farklı özellikleri olan yabancı uyruklu öğrencilerin Türk okullarına kaydırılmasıyla birlikte okul ve sinıf ortamlarında çeşitli nedenlere bağlı olarak istenmeyen davranışlar izlenebilmektedir. İstenmeyen davranışların türleri, sergilenme sıklığı, hangi durumlarda sergilendikleri, bu davranışların sebeplerinin araştırılması ve eğitimcilerle paylaşılması önemlidir.

İstenmeyen davranış, öğretmenin derse olan dikkatine, öğrencinin kendisiyle beraber diğer öğrencilerin bir şeyler öğrenmesine engel olan, öğrenme-öğretme ortamını doğrudan veya dolaylı olarak bozan davranışlardır (Burden, 1995). Sosyal ve çevresel etkenler, ailenin yaşam stili ve ekonomik nedenler, devletin eğitim politikaları, eğitimin altyapısı ve donanımı, kültür ve değer farklılıkları gibi çeşitli nedenlerle öğrenciler; okul veya sinıflarda çeşitli istenmeyen davranışlar yapabilirler. Sınıf öğretmenleri, karşılaştıkları bu davranışları engellemek ve davranış bozukluğunu gidermek için bir takım yöntemleri uygulayabilirler. $\mathrm{Bu}$ açıdan eğitimcilerin istenmeyen davranışları düzeltebilmeleri ve bu davranışlarla etkili yöntemleri kullanarak baş edebilmeleri için bu davranışların kaynağı bilinmelidir (Karadağ ve Üney, 2006: 129).

Alan yazın incelendiğinde, sınıf içi istenmeyen davranışlarla ilgili birçok araştırmaya rastlanmıştır (Cebeci, 2016; Geiger, 2000, Gottfredson ve Gottfredson, 2001; Guttmann, 1982; Kay1kc1, 2013; Keyik, 2014; K1lıçoğlu, 


\section{A. Delen-M.H. Ercoskun $\quad$ Yabancı Uyruklu Öğrencilerin Bulunduğu...}

2015; Ünüvar, 2014), ancak yabancı uyruklu öğrencilerin bulunduğu ilkokullarda sınıf öğretmenlerinin karşılaştığı istenmeyen davranışlar ile ilgili çalışmaya rastlanamamıştır. $\mathrm{Bu}$ nedenle bu çalı̧̧mada, öğretmen görüşlerine göre; ilkokullarda birlikte eğitim gören Türk ve yabancı uyruklu öğrencilerde istenmeyen davranışların görülme sıklığı ve bu davranışların bu öğrencilerde farklılık gösterip göstermediği, istenmeyen davranışların nedenlerinin neler olabileceği, yabancı öğrencilerin Türk eğitim sistemine alınmalarının çeşitli değişkenler açısından (öğretmenlerin cinsiyeti, sınıftaki yabancı uyruklu öğrenci sayıs1 ve öğretmenlerin yabancı dil bilme durumlarına göre) değişip değişmediği araştırılmıştır. Araştırmanın bu temel problemine göre şu sorulara cevap aranmıştır;

1) İstenmeyen davranışların Türk ve yabanc1 uyruklu öğrencilerde gerçekleşme düzeyi nasıldır?

2) Türk ve yabancı uyruklu öğrencilerdeki istenmeyen davranışlar farklı midir?

3) Türk ve yabancı uyruklu öğrencilerde istenmeyen davranışların nedenleri farklı midır?

4) İstenmeyen davranışların gerçekleşme düzeyi ve nedenleri öğretmenlerin cinsiyetine göre farklılaşmakta mıdır?

5) İstenmeyen davranışların gerçekleşme düzeyi sınıftaki yabancı uyruklu öğrenci sayısına göre farklılaşmakta mıdır?

6) İstenmeyen davranışların gerçekleşme düzeyi öğretmenlerin hangi yabancı dili bilip bilmemelerine göre farklılaşmakta mıdır?

\section{YÖNTEM}

$\mathrm{Bu}$ çalışmada genel amaca ve alt problemlere uygun olarak nicel araştırma yöntemlerinden betimsel tarama modeli kullanılmıştır. Karasar’a (2013) göre tarama modeli, geçmişte ya da halen var olan bir durumu, olduğu şekliyle betimlemeyi amaçlayan araştırma yaklaşımıdır ve olayların, objelerin, varlıkların, kurumların, grupların ve çeşitli alanların "ne" olduğunu betimlemeye, açıklamaya çalışan betimsel çalışmalardır.

\section{Evren ve Örneklem}

Bu çalışmanın evreni 2016-17 öğretim yılında Mardin ili Midyat ilçesinde yabancı uyruklu öğrencilerin yoğun olduğu 12 devlet ilkokulundaki 234 sinıf öğretmeni ve Midyat konaklama tesisinde çalışan 26 geçici Türkçe öğreticisi 
olmak üzere toplamda 260 öğretmenden oluşmuştur. Veri toplama sürecinde evrenin hepsine ulaşıldığından evrenden örneklem alınmamıştır.

\section{Veri Toplama Aracı}

Araştırmada veri toplamak için; Sadık'ın (2000) yazdığ 1 “İlköğretim I. Aşama Sınıf Öğretmenlerinin Sınıfta Gözlemledikleri Problem Davranışlar” isimli yüksek lisans tezi için geliştirilen anket, geliştiriciden gerekli izin alındıktan sonra araştırma için biçimsel açıdan yeniden düzenlenerek uygulanmıştır. Orijinal anket 61 maddedir. Bu çalışmada, araştırmacı anketin güvenirliğini arttırmak ve maddelerin iyice düşünülüp yanıtlandığından emin olabilmek için kontrol maddesi olan 55. maddeyi (Lütfen bu maddeyi boş bırakınız) eklenmiş ve madde sayısı 62 olmuştur. Böylece bu maddeyi işaretleyenlerin anketleri değerlendirme dışı bırakılmıştır (Lake ve Harper, 2008: 67).

Anket, üç bölümdür. Birinci bölüm kişisel bilgilerden, ikinci bölüm sınıf içi istenmeyen davranışların Türk ve yabancı uyruklu öğrencilerde gerçekleşme düzeyini gösteren 4'lü (1: Hiç, 2: Ara sıra, 3: Genellikle ve 4: Her zaman) likert tipi maddelerden ve üçüncü bölüm Türk ve yabancı uyruklu öğrencilerde görülen istenmeyen davranışların nedenlerini içeren maddelerden oluşturulmuştur.

\section{Verilerin Çözümlenmesi}

Anketler uygulandıktan sonra hatalı işaretlenen anketler değerlendirmeye alınmamıştır. Anketlerden elde edilen veriler kodlanmış ve SPSS paket programına aktarılmıştır. Elde edilen yüzde ve frekanslara bakılarak araştırmanın problemi ve alt problemlerine yönelik yorumlar yapılmıştır.

\section{BULGULAR}

$\mathrm{Bu}$ bölümde elde edilen verilere uygun olarak bulgular ve yorumlar verilmiştir. Bulgular kısmını çok fazla tablo ile doldurmamak, en önemli görülen bulgulara yer vermek ve diğer istenmeyen davranışlara daha az rastlandığ için öğretmenlerin öğrencilerinde en fazla gördüklerini belirttikleri ilk 3 istenmeyen davranışa sadece tablolarda yer verilmiştir. Aşağıda Tablo 1'de araştırmaya katılan öğretmenlerin görüşlerine göre Türk öğrenciler için her düzeyde en yüksek frekansı olan ilk 3 istenmeyen davranışa ilişkin bulgular verilmiş ve bu durumun yabancı uyruklu öğrencilerle karşılaştırılabilmesi için yorum Tablo 2'den sonra yapılmıştır. 


\section{A. Delen-M.H. Ercoskun $\quad$ Yabancı Uyruklu Öğrencilerin Bulunduğu...}

Tablo 1. Türk Öğrencilerde İstenmeyen Davranışların Gerçekleşme Düzeyi

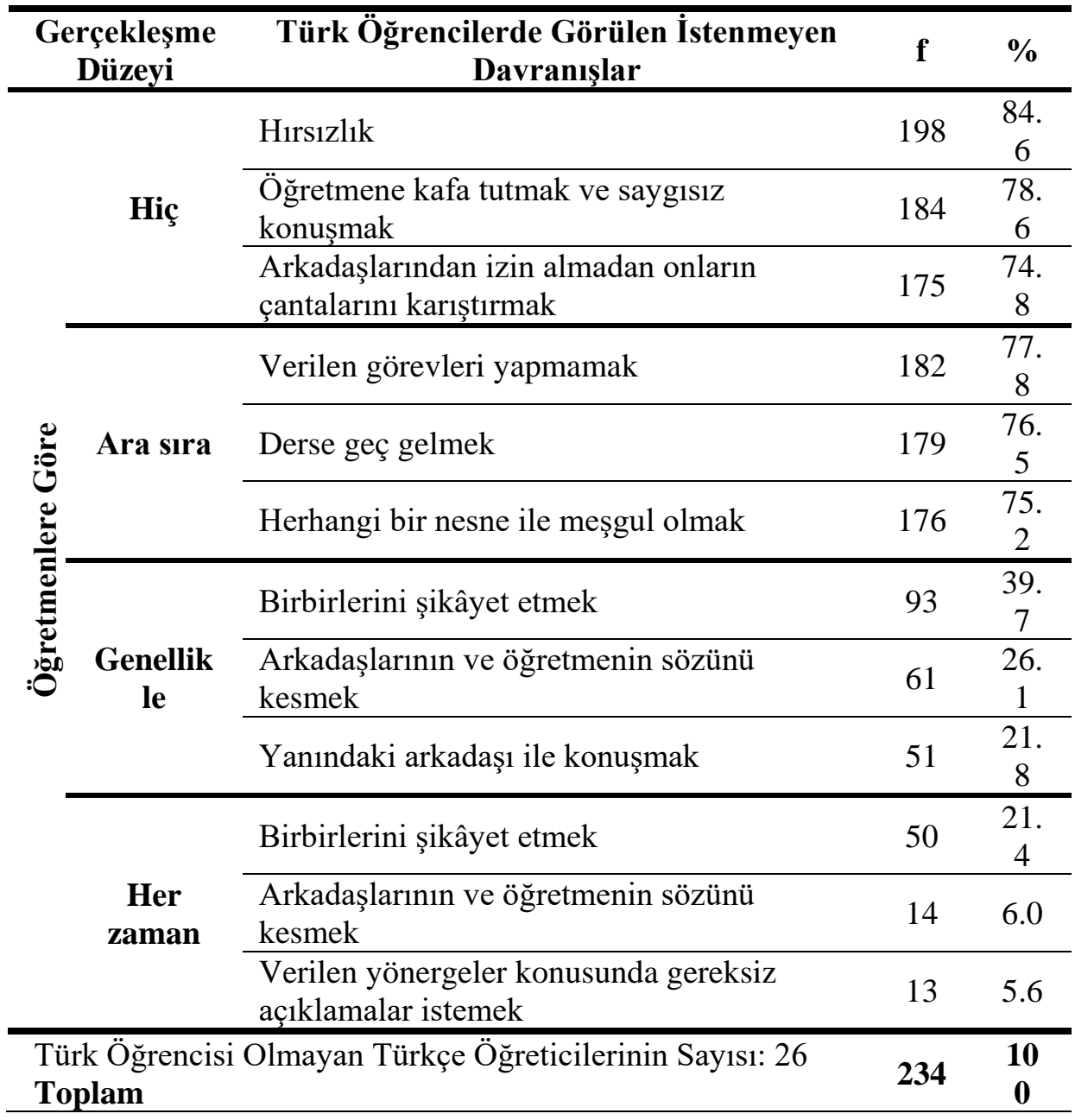

Tablo 1'de öğretmenlere göre; Türk öğrencilerde "Hiç" rastlanmayan istenmeyen davranışlardan en çok işaretlenenlerin; hırsızlık (\%84.6), öğretmene kafa tutmak ve saygısız konuşmak (\%78.6), arkadaşlarından izin almadan onların çantalarını karıştırmak (\%74.8) olduğu dikkat çekmektedir. Öğretmenler; verilen görevleri yapmamak (\%77.8), derse geç gelmek (\%76.5), herhangi bir nesne ile meşgul olmak (\%75.2) gibi istenmeyen davranışlara "Ara sıra"; birbirlerini şikayet etmek (\%39.7), arkadaşlarının ve öğretmenin sözünü kesmek (\%26.1), yanındaki arkadaşı ile konuşmak (\%21.8) gibi istenmeyen davranışlara "Genellikle"; birbirlerini șikayet etmek (\%21.4), arkadașlarının ve öğretmenin sözünü kesmek (\%6), verilen yönergeler konusunda gereksiz açılamalar istemek 
(\%5.6) gibi istenmeyen davranışlara ise "Her zaman" rastladıklarını söylemişlerdir.

Aşağıda Tablo 2'de araştırmaya katılan öğretmenlerin görüşlerine göre yabancı uyruklu öğrencilerde her düzeyde en yüksek frekansa sahip olan ilk 3 istenmeyen davranışa ilişkin bulgular verilmiş ve bu durumun Türk öğrencilerle karşılaştırılabilmesi için yorum birlikte yapılmıştır.

Tablo 2. Yabancı Uyruklu Öğrencilerde İstenmeyen Davranışların Gerçekleşme Düzeyi

\begin{tabular}{|c|c|c|c|c|}
\hline \multicolumn{2}{|c|}{$\begin{array}{l}\text { Gerçekleş } \\
\text { me Düzeyi }\end{array}$} & $\begin{array}{c}\text { Yabancı Uyruklu Öğrencilerde Görülen } \\
\text { İstenmeyen Davranıșlar }\end{array}$ & f & $\%$ \\
\hline \multirow{12}{*}{ 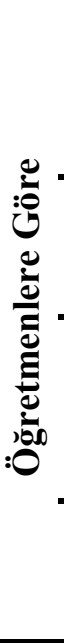 } & \multirow{3}{*}{ Hiç } & Öğretmene kafa tutmak ve saygısız konuşmak & 176 & 77.2 \\
\hline & & Sınıf dolabını izinsiz kullanmak ve karıştırmak & 166 & 72.8 \\
\hline & & $\begin{array}{l}\text { Farklı düşünen öğrencileri kendi gibi } \\
\text { düşünmeye zorlamak }\end{array}$ & 161 & 70.6 \\
\hline & \multirow{3}{*}{$\begin{array}{l}\text { Ara } \\
\text { sira }\end{array}$} & Sinıf içinde bir şeyler yemek & 144 & 63.2 \\
\hline & & Sirasında düzgün oturmamak & 136 & 59.6 \\
\hline & & Ders araç-gereçlerini temiz kullanmamak & 131 & 57.5 \\
\hline & \multirow{3}{*}{$\begin{array}{l}\text { Genel } \\
\text { likle }\end{array}$} & Yanındaki arkadaşıyla konuşmak & 88 & 38.6 \\
\hline & & Herhangi bir nesne ile meşgul olmak & 85 & 37.3 \\
\hline & & $\begin{array}{l}\text { Çalışmaya başlarken veya bitirirken yavaş } \\
\text { davranmak }\end{array}$ & 85 & 37.3 \\
\hline & \multirow{3}{*}{$\begin{array}{c}\text { Her } \\
\text { zama } \\
\text { n }\end{array}$} & Birbirlerini şikâyet etmek & 39 & 17.1 \\
\hline & & Ders dișında bir işle uğraşmak & 36 & 15.8 \\
\hline & & Ödevlerini geliși güzel ve eksik yapmak & 34 & 14.9 \\
\hline \multicolumn{3}{|c|}{$\begin{array}{l}\text { Yabancı Uyruklu Öğrencisi Olmayan Sınıf Öğretmenlerinin } \\
\text { Sayıs1: } 32 \text { Toplam }\end{array}$} & 228 & 100 \\
\hline
\end{tabular}

Tablo 2 incelendiğinde öğretmenlere göre; yabanc1 uyruklu öğrencilerde "Hiç" rastlanmayan istenmeyen davranışlardan en çok işaretlenenler, öğretmene kafa tutmak ve saygısız konuşmak (\%77.2), sınıf dolabını izinsiz kullanmak ve karıştırmak (\%72.8), hırsızlık (\%70.6)'tır. Öğretmenler; sınıf içinde bir şeyler yemek (\%63.2), sırasında düzgün oturmamak (\%59.6), ders araç-gereçlerini temiz kullanmamak (\%57.5) gibi davranışlara "Ara sıra"; yanındaki arkadaşıyla konuşmak (\%38.6), herhangi bir nesne ile meşgul olmak (\%37.3), çalışmaya başlarken veya bitirirken yavaş davranmak (\%37.3) gibi istenmeyen davranışlara "Genellikle"; birbirlerini şikayet etmek (\%17.1), ders dışında bir işle uğraşmak (\%15.8), ödevlerini gelişi güzel ve eksik yapmak (\%14.9) gibi istenmeyen davranışlara ise "Her zaman" rastladıklarını ileri sürmüşlerdir. 


\section{A. Delen-M.H. Ercoskun $\quad$ Yabancı Uyruklu Öğrencilerin Bulunduğu...}

$\mathrm{Bu}$ bulgular irdelendiğinde yabancı uyruklu öğrencilerin Türk öğrencilere göre birbirlerini daha az şikâyet ettikleri, yabancı uyruklu öğrencilerin geldikleri ülkelerde kendi kültürlerine göre normal olan davranışları (sınıfta bir şeyler yemek, sırasında düzgün oturmamak, ders araç-gereçlerini düzgün kullanmamak... vb) yine sürdürdükleri söylenebilir. Öğretmenlere göre; yabancı uyruklu öğrencilerin dil ve iletişim problemlerinden dolayı ders dışı şeylerle ilgilendikleri ve ödevlerini gelişi güzel şekilde yaptıkları ifade edilebilir.

Aşağıda Tablo 3'te bu çalışmaya katılan öğretmenlerin görüşlerine göre Türk öğrencilerde istenmeyen davranışlara tamamen veya kısmen neden olan ve en yüksek frekansa sahip olan ilk 3 etken ile neden olarak görülmeyen en yüksek frekansa sahip ilk 3 etkene ilişkin bulgu ve yorumlar verilmiştir.

Tablo 3. Öğretmenlerin Görüşlerine Göre Türk Öğrencilerde Görülen İstenmeyen Davranışların Nedenleri

\begin{tabular}{|c|c|c|c|c|}
\hline & & İstenmeyen Davranışların Nedenleri & $\mathbf{f}$ & $\%$ \\
\hline \multirow{9}{*}{ 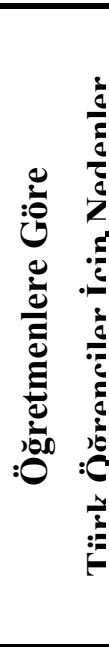 } & \multirow[t]{3}{*}{ Evet } & $\begin{array}{l}\text { Bilgisayar oyunları, TV dizileri vb. gibi } \\
\text { medya ve kitle iletişim araçlarının } \\
\text { olumsuz etkileri }\end{array}$ & 139 & 59.4 \\
\hline & & Kalabalık sınıflar & 114 & 48.7 \\
\hline & & Ailevi nedenler & 95 & 40.6 \\
\hline & \multirow[t]{3}{*}{ Kismen } & $\begin{array}{l}\text { Öğrencinin fiziksel ve sosyal gelişim } \\
\text { özelliklerinin uygun olmamas1, öğrenme } \\
\text { güçlüğü çekmesi ve akademik yetersizlik }\end{array}$ & 149 & 63.7 \\
\hline & & Arkadaş çevresi & 138 & 59.0 \\
\hline & & Okul ve sınıfların fiziki yetersizliği & 129 & 55.1 \\
\hline & \multirow{3}{*}{ Hay } & Okullarda ikili eğitimin yapılmas1 & 158 & 67.5 \\
\hline & & $\begin{array}{l}\text { Okul yönetiminin ilgisizliği ve } \\
\text { başıboşluk }\end{array}$ & 138 & 59.0 \\
\hline & & Sınıf kurallarının belirsizliği & 137 & 58.5 \\
\hline \multicolumn{3}{|c|}{$\begin{array}{l}\text { Türk Öğrencisi Olmayan Türkçe Öğreticilerinin Sayısı: } 26 \\
\text { Toplam }\end{array}$} & 234 & 100 \\
\hline
\end{tabular}

Tablo 3'e bakıldığında öğretmenlere göre Türk öğrencilerde görülen istenmeyen davranışların nedenlerinin arasında en çok; bilgisayar oyunları, TV dizileri vb. gibi medya ve kitle iletişim araçlarının olumsuz etkileri (\%59.4), kalabalık sınıflar (\%48.7), ailevi nedenler (\%40.6) belirtilmiştir. Öğretmenler tarafından; öğrencinin fiziksel ve sosyal gelişim özelliklerinin uygun olmaması, öğrenme güçlüğü çekmesi ve akademik yetersizlik (\%63.7), arkadaş çevresi (\%59.0) ile okul ve sınıfların fiziki yetersizliği (\%55.1) gibi etkenler "Kısmen" 
neden olarak belirtilirken; okullarda ikili eğitimin yapılmas1 (\%67.5), okul yönetiminin ilgisizliği ve başıboşluk (\%59), sınıf kurallarının belirsizliği (\%58.5) gibi etkenler, Türk öğrencilerin istenmeyen davranış sergilemelerine neden olan etkenler olarak belirtilmemiştir.

Aşağıda Tablo 4'te araştırmaya katılan öğretmenlerin görüşlerine göre yabancı uyruklu öğrencilerde istenmeyen davranışlara tamamen veya kısmen neden olan ve yüksek frekansa sahip olan ilk 3 etken ile neden olarak görülmeyen en yüksek frekansa sahip ilk 3 etkene ilişkin bulgu ve yorumlar vardır.

Tablo 4. Öğretmenlerin Görüşlerine Göre Yabancı Uyruklu Öğrencilerde Görülen İstenmeyen Davranışların Nedenleri

\begin{tabular}{|c|c|c|c|c|}
\hline & & $\begin{array}{c}\text { İstenmeyen Davranışların } \\
\text { Nedenleri } \\
\end{array}$ & f & $\%$ \\
\hline \multirow{9}{*}{ 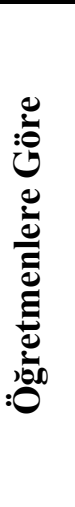 } & \multirow{3}{*}{ Evet } & Toplumsal ve kültürel değişim/göç & 179 & 78.9 \\
\hline & & Aile içi nedenler & 140 & 61.7 \\
\hline & & Dil ve iletişim problemleri & 139 & 61.2 \\
\hline & \multirow{3}{*}{ Kismen } & Öğretim yöntemleri & 134 & 59.0 \\
\hline & & Okulun bulunduğu çevre & 123 & 54.2 \\
\hline & & $\begin{array}{l}\text { Ders içeriklerinin öğrencinin ilgi ve } \\
\text { ihtiyaçlarına uygun olmaması }\end{array}$ & 119 & 52.4 \\
\hline & \multirow{3}{*}{ Hayır } & Okulda ikili eğitimin yapılmas1 & 141 & 62.1 \\
\hline & & $\begin{array}{l}\text { Okul yönetiminin ilgisizliği ve } \\
\text { başıoșluk }\end{array}$ & 133 & 58.6 \\
\hline & & Sinif tekrar1 & 126 & 55.6 \\
\hline \multicolumn{3}{|c|}{$\begin{array}{l}\text { Yabancı Uyruklu Öğrencisi Olmayan Öğretmenlerin Sayısı: } \\
32 \quad \text { Toplam }\end{array}$} & 228 & 100 \\
\hline
\end{tabular}

Tablo 4 incelendiğinde öğretmenlere göre yabanc1 uyruklu öğrencilerde görülen istenmeyen davranışların nedenlerinin arasında en çok; toplumsal ve kültürel değişim/göç (\%78.9), aile içi nedenler (\%61.7), dil ve iletişim problemleri (\%61.2) gibi nedenlerin olduğu dikkat çekmektedir. Öğretmenler tarafından; öğretim yöntemleri (\%59), okulun bulunduğu çevre (\%54.2), ders içeriklerinin öğrencinin ilgi ve ihtiyaçlarına uygun olmaması (\%52.4) gibi etkenler "Kısmen" neden olarak belirtilirken; okulda ikili eğitimin yapılması (\%62.1), okul yönetiminin ilgisizliği ve başıboşluk (\%58.6), sınıf tekrarı (\%55.6) gibi etkenler neden olarak belirtilmemiştir.

Aşağıda Tablo 5 ve 6'da araştırmaya katılan öğretmenlerin cinsiyetine göre Türk ve yabancı uyruklu öğrencilerde her düzeyde en yüksek frekansa sahip olan ilk 3 istenmeyen davranışa yönelik bulgu ve yorumlar verilmiştir. 


\section{A. Delen-M.H. Ercoskun $\quad$ Yabancı Uyruklu Öğrencilerin Bulunduğu...}

Tablo 5. Öğretmenlerin Cinsiyetine Göre Türk Öğrencilerde İstenmeyen

Davranışların Gerçekleşme Düzeyi

\begin{tabular}{|c|c|c|c|c|}
\hline \multicolumn{2}{|c|}{$\begin{array}{l}\text { Gerçekleşme } \\
\text { Düzeyi }\end{array}$} & $\begin{array}{l}\text { Türk Öğrencilerde Görülen } \\
\text { İstenmeyen Davranışlar }\end{array}$ & $\mathbf{f}$ & $\%$ \\
\hline \multirow{13}{*}{ 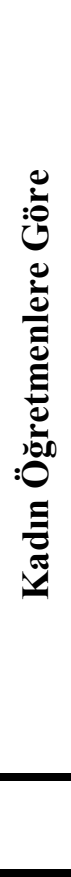 } & \multirow{3}{*}{ Hiç } & Hirs1zlik & 91 & 88.3 \\
\hline & & $\begin{array}{l}\text { Öğretmene kafa tutmak ve saygısız } \\
\text { konuşmak }\end{array}$ & 84 & 81.6 \\
\hline & & $\begin{array}{l}\text { Arkadaşlarından izin almadan onların } \\
\text { çantalarını karıştırmak }\end{array}$ & 82 & 79.6 \\
\hline & \multirow{3}{*}{ Ara sira } & Verilen görevleri yapmamak & 85 & 82.5 \\
\hline & & Herhangi bir nesne ile meşgul olmak & 77 & 74.8 \\
\hline & & Derse geç gelmek & 76 & 73.8 \\
\hline & \multirow{3}{*}{ Genellikle } & Birbirlerini şikâyet etmek & 39 & 37.9 \\
\hline & & $\begin{array}{l}\text { Arkadaşlarının ve öğretmeninin sözünü } \\
\text { keserek sırası gelmeden konuşmak }\end{array}$ & 26 & 25.2 \\
\hline & & Yanındaki arkadaşı ile konuşmak & 25 & 24.3 \\
\hline & \multirow{3}{*}{ Her zaman } & Birbirlerini şikâyet etmek & 25 & 24.3 \\
\hline & & $\begin{array}{l}\text { Verilen yönergeler konusunda gereksiz } \\
\text { açıklamalar istemek }\end{array}$ & 8 & 7.8 \\
\hline & & $\begin{array}{l}\text { Arkadaşlarının ve öğretmenin sözünü } \\
\text { keserek sırası gelmeden konuşmak }\end{array}$ & 6 & 5.8 \\
\hline & & $\begin{array}{r}\text { Türk Öğrencisi Olan Kadın } \\
\text { Öğretmenler }\end{array}$ & 103 & 44.0 \\
\hline \multirow{11}{*}{ 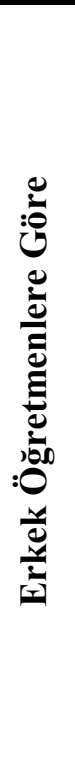 } & \multirow{3}{*}{ Hiç } & Hirsizlik & 107 & 81.7 \\
\hline & & $\begin{array}{l}\text { Öğretmene kafa tutmak ve saygisız } \\
\text { konuşmak }\end{array}$ & 100 & 76.3 \\
\hline & & $\begin{array}{l}\text { Arkadaşlarından izin almadan onların } \\
\text { çantalarını karıştırmak }\end{array}$ & 93 & 71.0 \\
\hline & \multirow{3}{*}{ Ara sira } & Derse geç gelmek & 103 & 78.6 \\
\hline & & Herhangi bir nesne ile meşgul olmak & 99 & 75.6 \\
\hline & & Verilen görevleri yapmamak & 97 & 74.0 \\
\hline & \multirow{3}{*}{ Genellikle } & $\begin{array}{l}\text { Arkadaşlarının ödevlerinden kopya } \\
\text { çekmek }\end{array}$ & 89 & 67.9 \\
\hline & & Birbirlerini şikâyet etmek & 54 & 41.2 \\
\hline & & $\begin{array}{l}\text { Arkadaşlarının ve öğretmeninin } \\
\text { sözünü keserek sırası gelmeden } \\
\text { konuşmak }\end{array}$ & 35 & 26.7 \\
\hline & \multirow[b]{2}{*}{ Her zaman } & Birbirlerini şikâyet etmek & 25 & 19.1 \\
\hline & & $\begin{array}{l}\text { Arkadaşlarının ödevlerinden kopya } \\
\text { çekmek }\end{array}$ & 11 & 8.4 \\
\hline
\end{tabular}




\begin{tabular}{|c|c|c|c|}
\hline & $\begin{array}{l}\text { Arkadaşlarının ve öğretmenin sözünü } \\
\text { keserek sırası gelmeden konuşmak }\end{array}$ & 8 & 6.1 \\
\hline & $\begin{array}{r}\text { Türk Öğrencisi Olan Erkek } \\
\text { Öğretmenler }\end{array}$ & 131 & 56.0 \\
\hline $\begin{array}{l}\text { Türk Öğrencisi Olmadı̆̆ } 11 \\
\text { Ögreticilerinin Sayısı: } 26 \\
\text { Toplam }\end{array}$ & 6 & 234 & 100 \\
\hline
\end{tabular}

Tablo 6. Öğretmenlerinin Cinsiyetine Göre Yabancı Uyruklu Öğrencilerde İstenmeyen Davranışların Gerçekleşme Düzeyi

\begin{tabular}{|c|c|c|c|c|}
\hline \multicolumn{2}{|c|}{$\begin{array}{c}\text { Gerçekleşme } \\
\text { Düzeyi }\end{array}$} & $\begin{array}{l}\text { Yabancı Uyruklu Öğrencilerde } \\
\text { Görülen İstenmeyen Davranıșlar }\end{array}$ & f & $\%$ \\
\hline \multirow{12}{*}{ 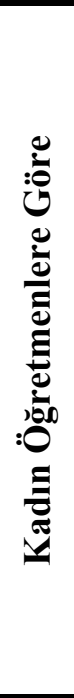 } & \multirow{3}{*}{ Hiç } & $\begin{array}{l}\text { Öğretmene kafa tutmak ve saygisız } \\
\text { konuşmak }\end{array}$ & 84 & 83.2 \\
\hline & & Sınıf dolabını izinsiz kullanıp karıştırmak & 82 & 81.2 \\
\hline & & $\begin{array}{l}\text { Arkadaşlarından izin almadan onların } \\
\text { çantalarını karıştırmak }\end{array}$ & 80 & 79.2 \\
\hline & \multirow{3}{*}{ Ara sira } & Sınıf içinde bir şeyler yemek & 63 & 62.4 \\
\hline & & Ders-gereçlerini temiz kullanmamak & 56 & 55.4 \\
\hline & & Sirasında düzgün oturmamak & 55 & 54.5 \\
\hline & \multirow{3}{*}{ Genellikle } & Herhangi bir nesne ile meşgul olmak & 36 & 35.6 \\
\hline & & Ders araç-gereçlerini eksik getirmek & 35 & 34.7 \\
\hline & & Yanındaki arkadaşı ile konuşmak & 34 & 33.7 \\
\hline & \multirow{4}{*}{$\begin{array}{c}\text { Her } \\
\text { zaman }\end{array}$} & Ödevlerini eksik ya da gelişigüzel yapmak & 20 & 19.8 \\
\hline & & Birbirlerini şikâyet etmek & 17 & 16.8 \\
\hline & & $\begin{array}{l}\text { Sürekli konuşarak diğer arkadaşlarını } \\
\text { çalışmalarında rahatsız etmek }\end{array}$ & 16 & 15.8 \\
\hline & & $\begin{array}{r}\text { Yabancı Uyruklu Öğrencisi Olan Kadın } \\
\text { Öğretmenler }\end{array}$ & 101 & 44.3 \\
\hline \multirow{7}{*}{ 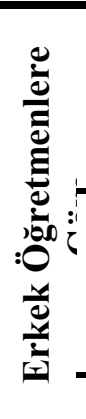 } & \multirow{3}{*}{ Hiç } & $\begin{array}{l}\text { Öğretmene kafa tutmak ve saygisız } \\
\text { konuşmak }\end{array}$ & 92 & 72.4 \\
\hline & & Hirsızlık & 85 & 66.9 \\
\hline & & Sınıf dolabını izinsiz kullanıp karıştırmak & 84 & 66.1 \\
\hline & \multirow{3}{*}{ Ara sira } & Sinıf içinde bir şeyler yemek & 81 & 63.8 \\
\hline & & Sırasında düzgün oturmamak & 81 & 63.8 \\
\hline & & $\begin{array}{l}\text { Elindeki bir nesne ile kap1, sıra ya da } \\
\text { duvarlara vurarak ses çıkarmak }\end{array}$ & 76 & 59.8 \\
\hline & Genellikle & Yanındaki arkadaşı ile konuşmak & 54 & 42.5 \\
\hline
\end{tabular}


A. Delen-M.H. Ercoskun $\quad$ Yabancı Uyruklu Öğrencilerin Bulunduğu...

\begin{tabular}{|c|c|c|c|}
\hline & $\begin{array}{l}\text { Çalışmaya başlarken veya bitirirken yavaş } \\
\text { davranmak }\end{array}$ & 53 & 41.7 \\
\hline & Birbirlerini şikâyet etmek & 50 & 39.4 \\
\hline \multirow{4}{*}{$\begin{array}{c}\text { Her } \\
\text { zaman }\end{array}$} & Ders dişında bir işle uğraşmak & 22 & 17.3 \\
\hline & Birbirlerini şikâyet etmek & 21 & 16.5 \\
\hline & Yanındaki arkadaşı ile konuşmak & 19 & 15.0 \\
\hline & $\begin{array}{r}\text { Yabancı Uyruklu Öğrencisi Olan Erkek } \\
\text { Öğretmenler }\end{array}$ & 127 & 55.7 \\
\hline \multicolumn{4}{|c|}{$\begin{array}{l}\text { Yabanc1 Uyruklu Öğrencisi Olmadığ İçin Görüş } \\
\text { Belirtmeyen Öğretmenlerin Sayıs1: } 32\end{array}$} \\
\hline
\end{tabular}

Tablo 5'e bakıldığında, Türk öğrencilerin "Hiç" sergilemediği ilk 3 istenmeyen davranışın, kadın ve erkek öğretmenler açısından aynı davranışların olduğu; ancak yüzde değerlerinin kadın öğretmenlerde daha yüksek olduğu dikkat çekmektedir. "Ara sıra" görülen istenmeyen davranışlardan en yüksek yüzdesi olan davranışların kadın ve erkek öğretmenler açısından aynı davranışların olduğu; ancak yüzde değerlerinin farklı olduğu görülmektedir. "Herhangi bir nesne ile meşgul olmak" istenmeyen davranışının yüzde değerinin kadın ve erkek öğretmenlerde birbirine yakın olduğu, "birbirlerini şikâyet etme" istenmeyen davranışının yüzde değerinin kadın öğretmenlerde daha yüksek olduğu, "derse geç gelme" istenmeyen davranışının yüzde değerinin erkek öğretmenlerde daha yüksek olduğu göze çarpmaktadır. "Genellikle" düzeyinde en çok görülen 3 istenmeyen davranıştan; "birbirlerini şikâyet etmek" ve "arkadaşlarının ve öğretmenin sözünü keserek sırası gelmeden konuşmak" istenmeyen davranışlarının kadın ve erkek öğretmenler tarafından belirtildiği görülmektedir. Türk öğrencilerin birbirlerini şikâyet etme istenmeyen davranış1 erkek öğretmenlere göre kadın öğretmenlerde daha yüksek yüzdeye sahiptir. Kadın öğretmenler, Türk öğrencilerin birbiriyle konuştuklarını belirtirken; erkek öğretmenler, arkadaşlarının ödevlerinden kopya çektiklerini ileri sürmüşlerdir. Türk öğrencilerin "her zaman" sergiledikleri istenmeyen davranışlar arasında en çok rastlanan 3 davranıştan biri olan "arkadaşlarının ve öğretmeninin sözünü kesmek” istenmeyen davranışının, kadın ve erkek öğretmenler açısından neredeyse eşit yüzdeye sahiptir. Türk öğrencilerde "Her zaman" görülen istenmeyen davranışlardan; "birbirlerini şikâyet etme" istenmeyen davranışının kadın öğretmenlerde daha yüksek yüzdeye sahip olduğu dikkat çekmektedir. Türk öğrencilerde "Her zaman" düzeyinde en çok görülen istenmeyen davranışlardan "verilen yönergeler konusunda gereksiz açıklamalar istemek" istenmeyen davranışının kadın öğretmenler; "arkadaşlarının ödevlerinden kopya çekmek” istenmeyen davranışının erkek öğretmenler açısından en çok belirtilen istenmeyen davranışlar olduğu söylenebilir. Sonuç olarak sınıf öğretmenlerinin 
cinsiyetine göre Türk öğrencilerde istenmeyen davranışların gerçekleşme düzeyine bakıldığında her düzeyde (hiç, ara sıra, genellikle ve her zaman) istenmeyen davranışların ve bunların gerçekleşme yüzdelerinin birbirlerine yakın olduğu ifade edilebilir.

Tablo 6 incelendiğinde, Türk ve yabancı uyruklu öğrencilerde "Hiç" rastlanmayan istenmeyen davranışların benzer olduğu söylenebilir. "Ara sıra" düzeyinde görülen istenmeyen davranışlar, cinsiyet açısından biraz farklılık göstermiştir. Kadın öğretmenlere göre, yabanc1 uyruklu öğrencilerde kopya çekme ve verilen görevleri yapmama gibi istenmeyen davranışlar görülürken, erkek öğretmenlere göre; kadın öğretmenlerin sınıfindaki yabancı uyruklu öğrencilerin elindeki nesne ile masa, kapı ve duvarlara vurarak sesler çıkardıkları belirlenmiştir. Yabanc1 uyruklu öğrencilerde "Genellikle" görülen istenmeyen davranışların, öğretmenlerin cinsiyetine göre farklılık göstermediği söylenebilir. Yabancı uyruklu öğrencilerde birbirleriyle konuşma, herhangi bir nesne ile ilgilenme, çalışmaya başlarken ve bitirirken yavaş davranma gibi istenmeyen davranışların genellikle görüldüğü ileri sürülebilir. Yabancı uyruklu öğrencilerin "Her zaman" düzeyinde sergiledikleri istenmeyen davranışlar da öğretmenlerin cinsiyetine göre farkl11ık göstermemiştir. Öğretmenler; yabanc1 uyruklu öğrencilerin birbirleriyle konuşma, diğer arkadaşlarını rahatsız etme, araçgereçlerini eksik getirme ve herhangi bir nesne ile uğraşma gibi istenmeyen davranışları sıklıkla sergilediklerini ifade etmişlerdir.

Aşağıda Tablo 7'de araştırmaya katılan öğretmenlerin sınıflarındaki yabancı uyruklu öğrenci sayısına göre Türk ve yabancı uyruklu öğrenciler için her düzeyde en yüksek frekansa sahip olan ilk 3 istenmeyen davranışa ilişkin bulgu ve yorumlar görülmektedir.

Tablo 7. Sınıftaki Yabancı Uyruklu Öğrenci Sayısına Göre Türk Öğrencilerde İstenmeyen Davranışların Gerçekleşme Düzeyi

\begin{tabular}{|c|c|c|c|c|}
\hline \multicolumn{2}{|c|}{$\begin{array}{c}\text { Gerçekleşme } \\
\text { Düzeyi }\end{array}$} & $\begin{array}{l}\text { Türk Öğrencilerde Görülen } \\
\text { İstenmeyen Davranışlar }\end{array}$ & f & $\%$ \\
\hline \multirow{7}{*}{ 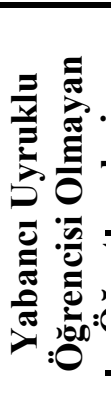 } & \multirow{3}{*}{ Hiç } & Hirsızlık & 31 & 96.9 \\
\hline & & $\begin{array}{l}\text { Arkadaşlarından izin almadan onların } \\
\text { cantalarını karıștırmak }\end{array}$ & 25 & 78.1 \\
\hline & & $\begin{array}{l}\text { Sınıf dolabını izinsiz kullanmak ve } \\
\text { karıştırmak }\end{array}$ & 25 & 78.1 \\
\hline & \multirow{4}{*}{$\begin{array}{l}\text { Ara } \\
\text { sira }\end{array}$} & Ders dişında bir işle uğraşmak & 28 & 87.5 \\
\hline & & Sırasında düzgün oturmamak & 27 & 84.4 \\
\hline & & Derse geç gelmek & 26 & 81.3 \\
\hline & & Birbirlerini şikâyet etmek & 15 & 46.9 \\
\hline
\end{tabular}




\section{A. Delen-M.H. Ercoskun $\quad$ Yabancı Uyruklu Öğrencilerin Bulunduğu...}

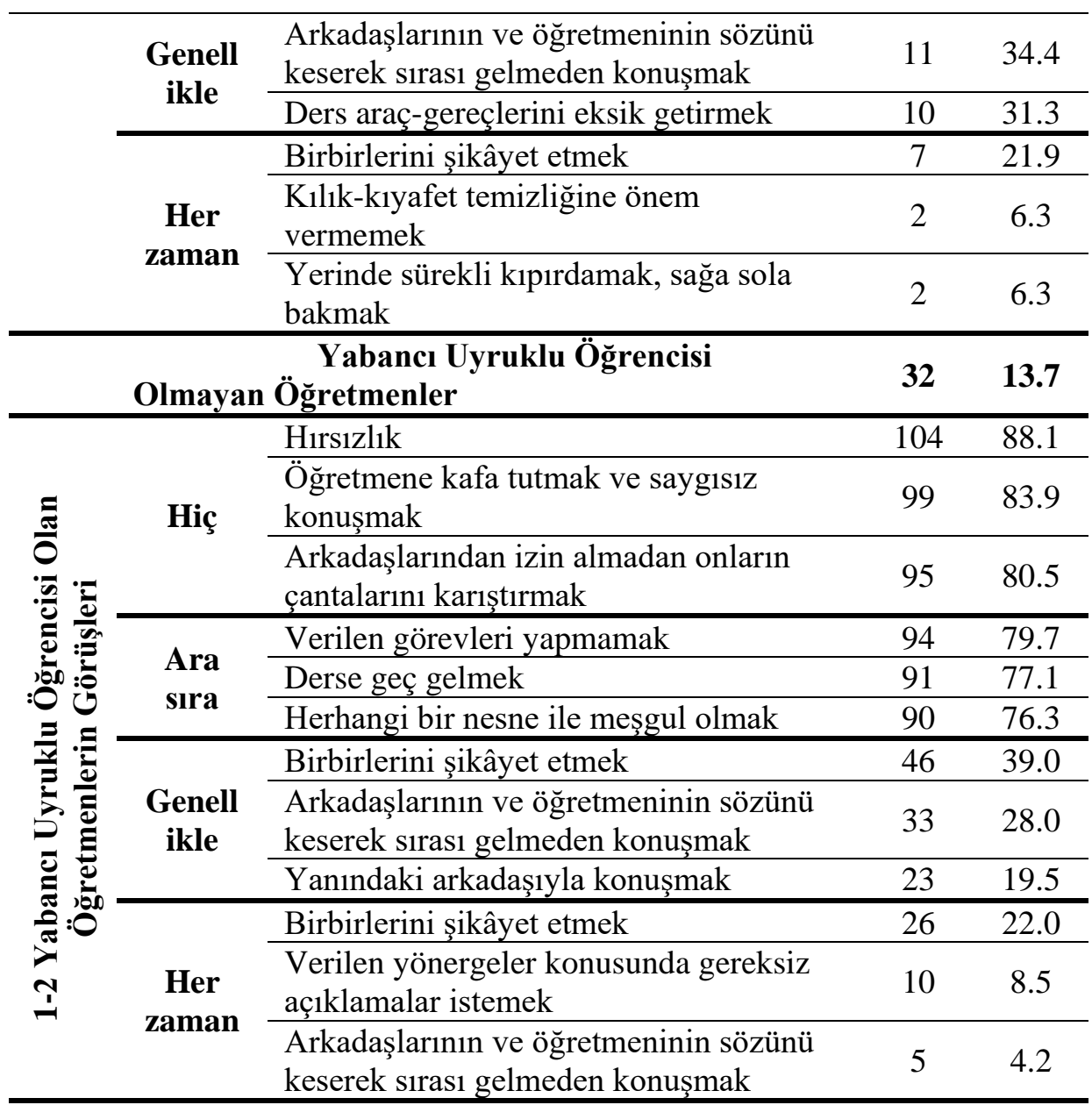

Tablo 7. (devami)

\begin{tabular}{|c|c|c|c|c|}
\hline & & $\begin{array}{r}\text { 1-2 Yabancı Uyruklu Öğgrencisi Olan } \\
\text { Öğretmenler }\end{array}$ & 118 & 50.4 \\
\hline \multirow{6}{*}{ 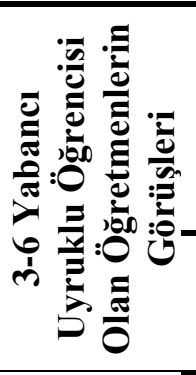 } & \multirow{3}{*}{ Hiç } & Hirsılik & 48 & 71.6 \\
\hline & & $\begin{array}{l}\text { Öğretmene kafa tutmak ve saygısız } \\
\text { konuşak }\end{array}$ & 47 & 70.1 \\
\hline & & $\begin{array}{l}\text { Sınıf dolabını izinsiz kullanmak ve } \\
\text { karıștırmak }\end{array}$ & 44 & 65.7 \\
\hline & \multirow{3}{*}{$\begin{array}{l}\text { Ara } \\
\text { sira }\end{array}$} & Ders dışında bir işle uğraşmak & 55 & 82.1 \\
\hline & & Verilen görevleri yapmamak & 54 & 80.6 \\
\hline & & Derse geç gelmek & 54 & 80.6 \\
\hline
\end{tabular}




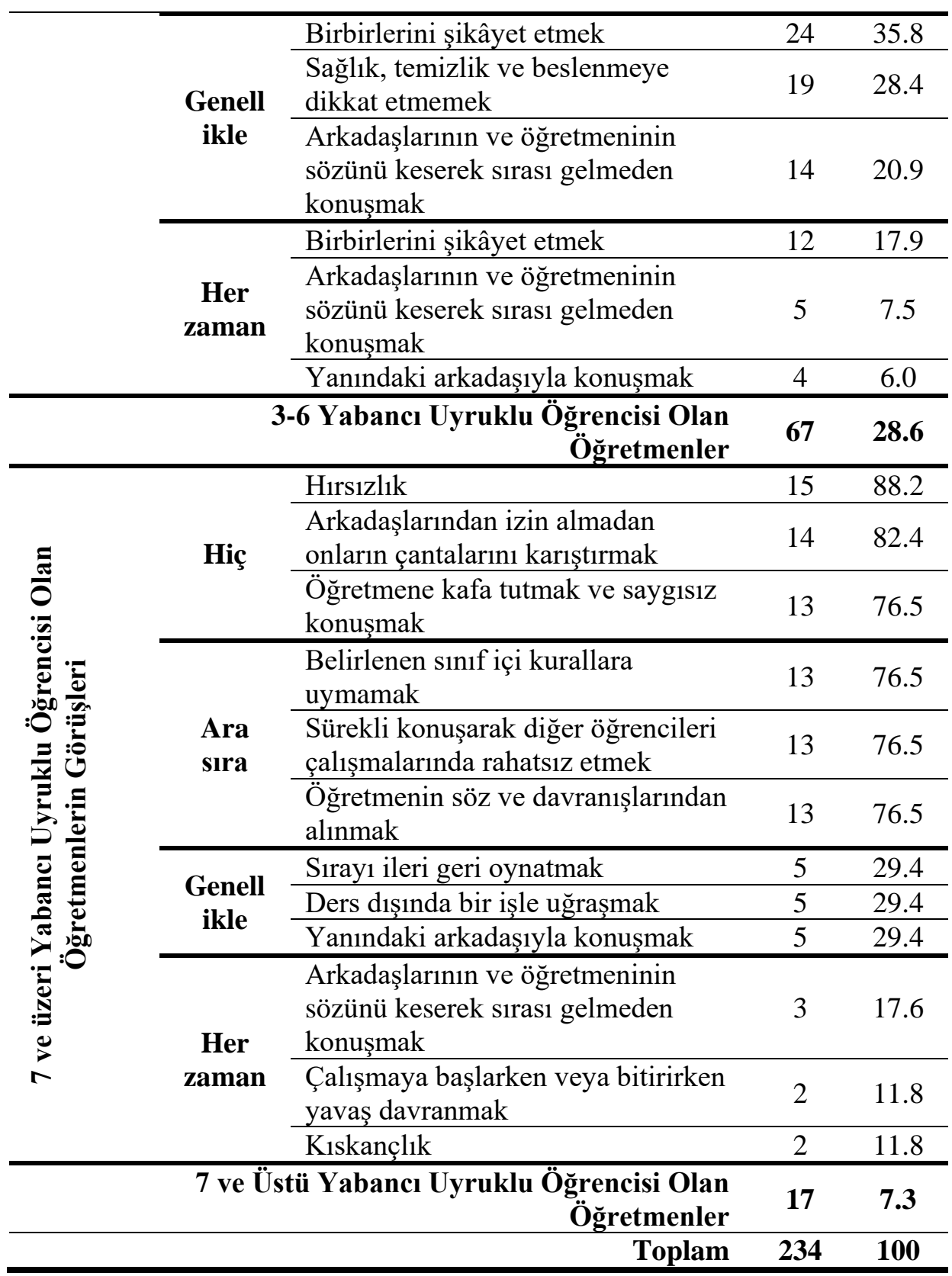




\section{A. Delen-M.H. Ercoskun $\quad$ Yabancı Uyruklu Öğrencilerin Bulunduğu...}

Tablo 8. Sınıftaki Yabancı Uyruklu Öğrenci Sayısına Göre Yabancı Uyruklu Öğrencilerde İstenmeyen Davranışların Gerçekleşme Düzeyi

\begin{tabular}{|c|c|c|c|c|}
\hline \multicolumn{2}{|c|}{$\begin{array}{l}\text { Gerçekleşme } \\
\text { Düzeyi }\end{array}$} & $\begin{array}{l}\text { Yabancı Uyruklu Öğrencilerde } \\
\text { Görülen İstenmeyen Davranışlar }\end{array}$ & $\mathbf{f}$ & $\%$ \\
\hline \multirow{12}{*}{ 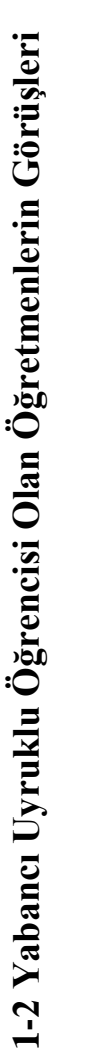 } & \multirow{3}{*}{ Hiç } & $\begin{array}{l}\text { Farklı düşünen öğrencileri kendileri } \\
\text { gibi düşünmeye zorlamak }\end{array}$ & 99 & $\begin{array}{c}83 . \\
9\end{array}$ \\
\hline & & $\begin{array}{l}\text { Öğretmene kafa tutmak ve saygısız } \\
\text { konuşmak }\end{array}$ & 98 & $\begin{array}{c}83 . \\
1\end{array}$ \\
\hline & & $\begin{array}{l}\text { Sınıf dolabını izinsiz kullanmak ve } \\
\text { karıştırmak }\end{array}$ & 96 & $\begin{array}{c}81 . \\
4\end{array}$ \\
\hline & \multirow{3}{*}{ Ara sira } & Sınıf içerisinde bir şeyler yemek & 75 & $\begin{array}{c}63 . \\
6\end{array}$ \\
\hline & & Sırasında düzgün oturmamak & 69 & $\begin{array}{c}58 . \\
5\end{array}$ \\
\hline & & Sirayı ileri geri oynatmak & 68 & $\begin{array}{c}57 . \\
6\end{array}$ \\
\hline & \multirow{3}{*}{ Genellikle } & $\begin{array}{l}\text { Çalışmaya başlarken ve bitirirken } \\
\text { yavaș davranmak }\end{array}$ & 49 & $\begin{array}{c}41 . \\
5\end{array}$ \\
\hline & & Herhangi bir nesne ile meşgul olmak & 45 & $\begin{array}{c}38 . \\
1\end{array}$ \\
\hline & & Yanındaki arkadaşıyla konuşmak & 44 & $\begin{array}{c}37 . \\
3\end{array}$ \\
\hline & \multirow{3}{*}{$\begin{array}{c}\text { Her } \\
\text { zaman }\end{array}$} & $\begin{array}{l}\text { Ödevlerini eksik veya gelişigüzel } \\
\text { yapmak }\end{array}$ & 27 & $\begin{array}{c}22 . \\
9\end{array}$ \\
\hline & & $\begin{array}{l}\text { Sürekli konuşarak yanındaki arkadaşı } \\
\text { rahatsız etmek }\end{array}$ & 22 & $\begin{array}{c}18 . \\
6\end{array}$ \\
\hline & & Ders dışında bir işle uğraşmak & 22 & $\begin{array}{c}18 . \\
6\end{array}$ \\
\hline & 1-2 Yabancı & Jyruklu Öğrencisi Olan Öğretmenler & $\begin{array}{c}11 \\
8\end{array}$ & 51. \\
\hline \multirow{5}{*}{ 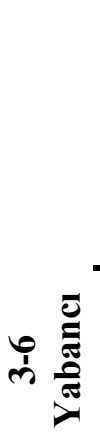 } & \multirow{3}{*}{ Hiç } & $\begin{array}{l}\text { Öğretmene kafa tutmak ve saygisız } \\
\text { konuşmak }\end{array}$ & 51 & $\begin{array}{c}76 . \\
1\end{array}$ \\
\hline & & $\begin{array}{l}\text { Sınıf dolabını izinsiz kullanmak ve } \\
\text { karıștırmak }\end{array}$ & 45 & $\begin{array}{c}67 . \\
2\end{array}$ \\
\hline & & Hirsılik & 43 & $\begin{array}{c}64 . \\
2\end{array}$ \\
\hline & \multirow{2}{*}{ Ara sira } & Sırasında düzgün oturmamak & 46 & $\begin{array}{c}68 . \\
7\end{array}$ \\
\hline & & Sınıf içerisinde bir şeyler yemek & 43 & $\begin{array}{c}64 . \\
2\end{array}$ \\
\hline
\end{tabular}




\begin{tabular}{|c|c|c|c|c|}
\hline & & $\begin{array}{l}\text { Yeni bir sınıf kuralına uyum } \\
\text { göstermemek }\end{array}$ & 42 & $\begin{array}{c}62 . \\
7 \\
\end{array}$ \\
\hline & \multirow{3}{*}{ Genellikle } & Ödevlerini eksik ve gelişigüzel yapmak & 27 & $\begin{array}{c}40 . \\
3\end{array}$ \\
\hline & & Yanındaki arkadaşıyla konuşmak & 24 & $\begin{array}{c}35 . \\
8\end{array}$ \\
\hline & & $\begin{array}{l}\text { Sağlık, hijyen ve dengeli beslenmeye } \\
\text { dikkat etmemek }\end{array}$ & 24 & $\begin{array}{c}35 . \\
8\end{array}$ \\
\hline & \multirow{3}{*}{$\begin{array}{c}\text { Her } \\
\text { zaman }\end{array}$} & Yanındaki arkadaşıyla konuşmak & 11 & $\begin{array}{c}16 . \\
4\end{array}$ \\
\hline & & Ders dışında bir işle uğraşmak & 9 & $\begin{array}{c}13 . \\
4\end{array}$ \\
\hline & & Birbirlerini şikâyet etmek & 9 & $\begin{array}{c}13 . \\
4\end{array}$ \\
\hline & 3-6 Yabanc & Uyruklu Öğrencisi Olan Öğretmenler & 67 & $\begin{array}{c}29 . \\
4\end{array}$ \\
\hline \multirow{12}{*}{ 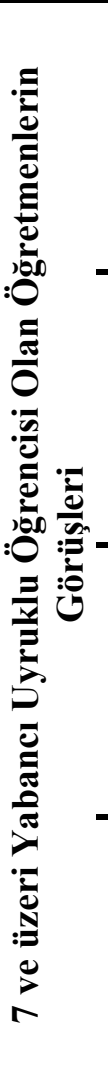 } & \multirow{3}{*}{ Hiç } & Hirsızlık & 31 & $\begin{array}{c}72 . \\
1\end{array}$ \\
\hline & & $\begin{array}{l}\text { Öğretmene kafa tutmak ve saygısız } \\
\text { konuşmak }\end{array}$ & 27 & $\begin{array}{c}62 . \\
8 \\
8\end{array}$ \\
\hline & & $\begin{array}{l}\text { Arkadaşlarından izin almadan onların } \\
\text { çantalarını karıştırmak }\end{array}$ & 25 & $\begin{array}{c}58 . \\
1 \\
\end{array}$ \\
\hline & \multirow{3}{*}{ Ara sira } & $\begin{array}{l}\text { Elindeki bir nesne ile kap1, sıra ya da } \\
\text { duvarlara vurarak gürültü yapmak }\end{array}$ & 30 & $\begin{array}{c}69 . \\
8 \\
\end{array}$ \\
\hline & & Yalan söylemek & 28 & $\begin{array}{c}65 . \\
1\end{array}$ \\
\hline & & Dersle ilgili aktivitelere katılmamak & 28 & $\begin{array}{c}65 . \\
1 \\
\end{array}$ \\
\hline & \multirow{3}{*}{ Genellikle } & Birbirlerini şikâyet etmek & 23 & $\begin{array}{c}53 . \\
5\end{array}$ \\
\hline & & Yanındaki arkadaşıyla konuşmak & 20 & $\begin{array}{c}46 . \\
5\end{array}$ \\
\hline & & $\begin{array}{l}\text { Sürekli konuşarak yanındaki arkadaşı } \\
\text { rahatsız etmek }\end{array}$ & 18 & $\begin{array}{c}41 . \\
9 \\
\end{array}$ \\
\hline & \multirow{3}{*}{$\begin{array}{c}\text { Her } \\
\text { zaman }\end{array}$} & Birbirlerini şikâyet etmek & 10 & $\begin{array}{c}23 . \\
3\end{array}$ \\
\hline & & Yanındaki arkadaşıyla konuşmak & 8 & $\begin{array}{c}18 . \\
6\end{array}$ \\
\hline & & $\begin{array}{l}\text { Sürekli konuşarak diğer arkadaşlarını } \\
\text { çalışmalarında rahatsız etmek }\end{array}$ & 6 & $\begin{array}{c}14 . \\
0\end{array}$ \\
\hline
\end{tabular}


A. Delen-M.H. Ercoskun $\quad$ Yabancı Uyruklu Öğrencilerin Bulunduğu...

\begin{tabular}{rrcc}
\hline 7 ve Daha Fazla Yabancı Uyruklu Öğrencisi Olan & \multirow{2}{*}{43} & $\begin{array}{c}18 . \\
\text { Öğretmenler }\end{array}$ & \multicolumn{9}{c}{9} \\
\hline Toplam & 22 & 100 \\
\hline
\end{tabular}

Tablo 7 incelendiğinde; sınıfında yabancı uyruklu öğrenci olan ve olmayan tüm öğretmenlerin Türk öğrencilerde, hırsızlık davranışıyla "Hiç" karşılaşmadıklarını belirttikleri söylenebilir. Sınıfında yabancı uyruklu öğrencisi olmayan öğretmenler ile sınıfında 1-2 ve 3-6 yabanc1 uyruklu öğrencisi olan öğretmenler, Türk öğrencilerin "Ara sıra" derse geç kaldıklarını ifade etmişlerdir. Sınıfında 1-2 ve 3-6 yabancı uyruklu öğrencisi olan öğretmenler, Türk öğrencilerin ara sıra verilen görevleri yapmadıklarını söylemişlerdir. Sınıfında 7 ve daha fazla yabancı uyruklu öğrencisi olan öğretmenler, Türk öğrencilerin ara sıra sınıf kurallarına uymadıklarını ve sürekli konuşarak diğer arkadaşlarını çalışmalarında rahatsız ettiklerini ileri sürmüşlerdir. Öğretmenlerin görüşlerine göre sınıfta yabancı uyruklu öğrenci sayısının artması, Türk öğrencilerin "Genellikle" sergiledikleri davranışlarında farklılık yaratabilir. Öğretmenlere göre; yabancı uyruklu öğrenci sayısının 6'ya kadar olduğu sınıflarda; Türk öğrencilerin birbirlerini şikâyet etmek, arkadaşlarının ve öğretmenin sözünü kesmek istenmeyen davranışlarını sergiledikleri; 7 ve daha fazla yabancı uyruklu öğrencinin olduğu sınıflarda Türk öğrencilerin, sırayı ileri geri oynattıkları, ders dışında bir şeyle uğraştıkları ve yanlarındaki arkadaşlarıyla konuştukları belirtilmiştir. Öğretmenlerin görüşlerine göre sınıfta yabancı uyruklu öğrenci sayısının artması, Türk öğrencilerin "Her zaman" sergiledikleri istenmeyen davranışlarında biraz olsa da farklılık yaratabilmektedir. Öğretmenlere göre; yabanc1 uyruklu öğrenci sayısı 6'ya kadar olan sınıflarda; Türk öğrencilerin sıklıkla birbirlerini şikâyet ettikleri, arkadaşlarının ve öğretmenin sözünü kestikleri ifade edilebilir. 7 ve daha fazla yabancı uyruklu öğrencinin olduğu sınıflarda ise; Türk öğrencilerin çalışmaya başlarken veya çalışmayı bitirirken yavaş oldukları ve kıskanç davrandıkları ifade edilmiştir.

Tablo 8'e bakıldığında; sınıfında yabancı uyruklu öğrencisi olan tüm öğretmenlerin yabanc1 uyruklu öğrencilerde, "öğretmene kafa tutmak ve saygısız konuşmak" istenmeyen davranışıyla "Hiç" karşılaşmadıkları ileri sürülebilir. 7 ve daha fazla yabancı uyruklu öğrencisi olan öğretmenler; yabancı uyruklu öğrencilerin ara sıra yalan söylediklerini, bir şeylere vurarak ses yaptıklarını ve dersteki etkinliklere katılmadıklarını belirtmişlerdir. Sınıfında 1-2 ile 3-6 yabancı uyruklu öğrencisi olan öğretmenler, yabancı uyruklu öğrencilerin ara sıra, sınıfta bir şeyler yediklerini ve sıralarında düzgün oturmadıklarını belirtmişlerdir. Sınıfinda yabancı uyruklu öğrencisi olan tüm öğretmenler, yabancı uyruklu öğrencilerin genel olarak, yanlarındaki arkadaşlarıyla konuştuklarını ifade etmişlerdir. Sınıfında 3-6 ile 7 ve daha fazla yabancı uyruklu öğrencisi olan 
öğretmenler, yabancı uyruklu öğrencilerin birbirleriyle konuştuklarını ve birbirlerini şikâyet ettiklerini ileri sürmüşlerdir. Sınıfinda 1-2 ile 3-6 yabancı uyruklu öğrencisi olan öğretmenler, yabancı uyruklu öğrencilerin ders diş1 şeylerle uğraştıklarını dile getirmişlerdir. Öğretmenlere göre sınıfta yabancı uyruklu öğrenci sayısının artması, yabancı uyruklu öğrencilerin sergiledikleri istenmeyen davranışlarda farklılığa neden olabilmektedir.

Aşağıda Tablo 9 ve 10'da araştırmaya katılan öğretmenlerin bildikleri yabancı dillere göre Türk öğrencilerde her düzeyde en yüksek frekansa sahip olan ilk 3 istenmeyen davranışa ilişkin bulgu ve yorumlar verilmiştir.

Tablo 9. Öğretmenlerin Bildikleri Yabancı Dillere Göre Türk Öğrencilerde İstenmeyen Davranışların Gerçekleşme Düzeyi

\begin{tabular}{|c|c|c|c|c|}
\hline \multicolumn{2}{|c|}{$\begin{array}{l}\text { Gerçekleşme } \\
\text { Düzeyi }\end{array}$} & $\begin{array}{c}\text { Türk Öğrencilerde Görülen İstenmeyen } \\
\text { Davranışlar }\end{array}$ & f & $\%$ \\
\hline \multirow{12}{*}{ 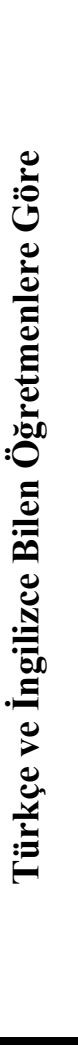 } & \multirow{3}{*}{ Hiç } & Hırsızlık & $\begin{array}{l}5 \\
0\end{array}$ & 87.7 \\
\hline & & $\begin{array}{l}\text { Öğretmene kafa tutmak ve saygisız } \\
\text { konuşmak }\end{array}$ & $\begin{array}{l}4 \\
3\end{array}$ & 75.4 \\
\hline & & $\begin{array}{l}\text { Sinıf dolabını izinsiz kullanmak ve } \\
\text { karıştırmak }\end{array}$ & $\begin{array}{l}4 \\
0\end{array}$ & 70.2 \\
\hline & \multirow{3}{*}{$\begin{array}{l}\text { Ara } \\
\text { sira }\end{array}$} & Verilen görevleri yapmamak & $\begin{array}{l}4 \\
2\end{array}$ & 73.7 \\
\hline & & Sinıf içinde bir şeyler yemek & $\begin{array}{l}3 \\
9\end{array}$ & 68.4 \\
\hline & & Derse geç gelmek & $\begin{array}{l}3 \\
9\end{array}$ & 68.4 \\
\hline & \multirow{3}{*}{$\begin{array}{l}\text { Genelli } \\
\text { kle }\end{array}$} & Birbirlerini șikâyet etmek & & 38.6 \\
\hline & & Yanındaki arkadaşı ile konuşmak & $\begin{array}{l}1 \\
9\end{array}$ & 33.3 \\
\hline & & $\begin{array}{l}\text { Arkadaşı ve öğretmeninin sözünü keserek } \\
\text { sırası gelmeden konuşmak }\end{array}$ & $\begin{array}{l}1 \\
6\end{array}$ & 28.1 \\
\hline & \multirow{4}{*}{$\begin{array}{c}\text { Her } \\
\text { zaman }\end{array}$} & $\begin{array}{l}\text { İzin almadan yerinden kalkmak ve } \\
\text { dolaşmak }\end{array}$ & $\begin{array}{l}2 \\
5\end{array}$ & 33.3 \\
\hline & & Birbirlerini şikâyet etmek & $\begin{array}{l}1 \\
6\end{array}$ & 28.1 \\
\hline & & $\begin{array}{l}\text { Arkadaşı ve öğretmeninin sözünü keserek } \\
\text { sırası gelmeden konuşmak }\end{array}$ & 4 & 7.0 \\
\hline & & $\begin{array}{r}\text { Türkçe ve İngilizce Bilen Öğretmen } \\
\text { Sayısı }\end{array}$ & $\begin{array}{l}5 \\
7\end{array}$ & 41.3 \\
\hline
\end{tabular}




\section{A. Delen-M.H. Ercoskun $\quad$ Yabancı Uyruklu Öğrencilerin Bulunduğu...}

\begin{tabular}{|c|c|c|c|c|}
\hline \multirow{12}{*}{ 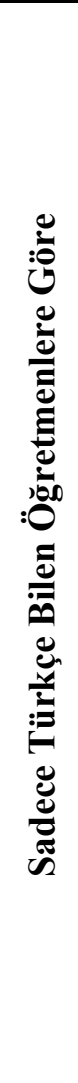 } & \multirow{3}{*}{ Hiç } & $\begin{array}{l}\text { Öğretmene kafa tutmak ve saygısız } \\
\text { konuşmak }\end{array}$ & $\begin{array}{l}6 \\
5\end{array}$ & 86.7 \\
\hline & & Hirsizlık & $\begin{array}{l}6 \\
5\end{array}$ & 86.7 \\
\hline & & $\begin{array}{l}\text { Arkadaşlarından izin almadan onların } \\
\text { çantalarını karıştırmak }\end{array}$ & $\begin{array}{l}6 \\
2\end{array}$ & 82.7 \\
\hline & \multirow{3}{*}{$\begin{array}{l}\text { Ara } \\
\text { sira }\end{array}$} & Herhangi bir nesne ile meşgul olmak & $\begin{array}{l}6 \\
6\end{array}$ & 88.0 \\
\hline & & Verilen görevleri yapmamak & $\begin{array}{l}6 \\
4\end{array}$ & 85.3 \\
\hline & & Derse geç gelmek & $\begin{array}{l}6 \\
1\end{array}$ & 81.3 \\
\hline & \multirow{3}{*}{$\begin{array}{l}\text { Genelli } \\
\text { kle }\end{array}$} & Birbirlerini şikâyet etmek & $\begin{array}{l}2 \\
7\end{array}$ & 36.0 \\
\hline & & $\begin{array}{l}\text { Arkadaş1 ve öğretmeninin sözünü keserek } \\
\text { sırası gelmeden konuşmak }\end{array}$ & $\begin{array}{l}2 \\
0\end{array}$ & 26.7 \\
\hline & & Belirlenen sınıf içi kurallara uymamak & $\begin{array}{l}1 \\
5\end{array}$ & 20.0 \\
\hline & \multirow{3}{*}{$\begin{array}{c}\text { Her } \\
\text { zaman }\end{array}$} & Birbirlerini şikâyet etmek & $\begin{array}{l}1 \\
4\end{array}$ & 18.7 \\
\hline & & $\begin{array}{l}\text { Verilen yönergeler konusunda gereksiz } \\
\text { açıklamalar istemek }\end{array}$ & 7 & 9.3 \\
\hline & & $\begin{array}{l}\text { Arkadaş1 ve öğretmeninin sözünü keserek } \\
\text { sıras1 gelmeden konuşmak }\end{array}$ & 5 & 6.7 \\
\hline
\end{tabular}

Tablo 9. (devam1)

\begin{tabular}{|c|c|c|c|c|}
\hline & & $\begin{array}{r}\text { Sadece Türkçe Bilen Öğretmen } \\
\text { Sayısı }\end{array}$ & 75 & 54.3 \\
\hline \multirow{8}{*}{ 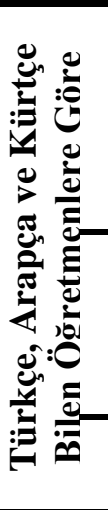 } & \multirow{3}{*}{ Hiç } & $\begin{array}{l}\text { Arkadaşlarından izin almadan onların } \\
\text { çantalarını karıştırmak }\end{array}$ & 6 & 100 \\
\hline & & $\begin{array}{l}\text { Sınıf dolabını izinsiz kullanmak ve } \\
\text { karıştırmak }\end{array}$ & 6 & 100 \\
\hline & & Hirsılik & 6 & 100 \\
\hline & \multirow{3}{*}{ Ara sıra } & Belirlenen sınıf içi kurallara uymamak & 6 & 100 \\
\hline & & Pencereden dışarıyı seyretmek & 6 & 100 \\
\hline & & $\begin{array}{l}\text { Verilen görevleri yapmamak ve derse } \\
\text { geç gelmek }\end{array}$ & 5 & 83.3 \\
\hline & \multirow{2}{*}{ Genellikle } & Birbirlerini şikâyet etmek & 4 & 66.7 \\
\hline & & Ders araç-gereçlerini eksik getirmek & 3 & 50.0 \\
\hline
\end{tabular}




\begin{tabular}{|c|c|c|c|}
\hline & $\begin{array}{l}\text { Arkadaş1 ve öğretmeninin sözünü } \\
\text { keserek sırası gelmeden konuşmak }\end{array}$ & 2 & 33.3 \\
\hline \multirow{5}{*}{ Her zaman } & Birbirlerini şikâyet etmek & 2 & 33.3 \\
\hline & $\begin{array}{l}\text { Verilen yönergeler konusunda gereksiz } \\
\text { açıklamalar istemek }\end{array}$ & 1 & 16.7 \\
\hline & - & - & - \\
\hline & $\begin{array}{r}\text { Türkçe, Arapça ve Kürtçe Bilen } \\
\text { Öğretmen Sayısı }\end{array}$ & 6 & 4.4 \\
\hline & Toplam & $\begin{array}{c}13 \\
8\end{array}$ & 100 \\
\hline
\end{tabular}

Tablo 10. Öğretmenlerin Bildikleri Yabancı Dillere Göre Yabancı Uyruklu Öğrencilerde İstenmeyen Davranışların Gerçekleşme Düzeyi

\begin{tabular}{|c|c|c|c|c|}
\hline \multicolumn{2}{|c|}{$\begin{array}{l}\text { Gerçekleşme } \\
\text { Düzeyi }\end{array}$} & $\begin{array}{l}\text { Yabancı Uyruklu Öğrencilerde } \\
\text { Görülen İstenmeyen Davranışlar }\end{array}$ & $\mathbf{f}$ & $\%$ \\
\hline \multirow{12}{*}{ 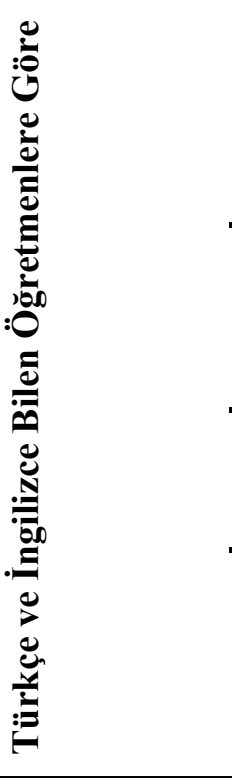 } & \multirow{3}{*}{ Hiç } & Hirsizlik & 36 & 72.0 \\
\hline & & $\begin{array}{l}\text { Farklı düşünen öğrencileri kendileri } \\
\text { gibi düşünmeye zorlamak }\end{array}$ & 34 & 68.0 \\
\hline & & $\begin{array}{l}\text { Öğretmene kafa tutmak ve saygısız } \\
\text { konuşmak }\end{array}$ & 33 & 66.0 \\
\hline & \multirow{3}{*}{$\begin{array}{l}\text { Ara } \\
\text { sira }\end{array}$} & Sınıf içerisinde bir şeyler yemek & 27 & 54.0 \\
\hline & & Sırasında düzgün oturmamak & 27 & 54.0 \\
\hline & & $\begin{array}{l}\text { Ders araç-gereçlerini temiz } \\
\text { kullanmamak }\end{array}$ & 27 & 54.0 \\
\hline & \multirow{3}{*}{$\begin{array}{c}\text { Ge } \\
\text { nell } \\
\text { ikle } \\
\end{array}$} & Ders dişında bir işle uğraşmak & 21 & 42.0 \\
\hline & & Herhangi bir nesne ile meşgul olmak & 21 & 42.0 \\
\hline & & Belirlenen sınıf içi kurallara uymamak & 21 & 42.0 \\
\hline & \multirow{3}{*}{$\begin{array}{c}\text { Her } \\
\text { za } \\
\text { ma } \\
\text { n }\end{array}$} & Yanındaki arkadaşıyla konuşmak & 14 & 28.0 \\
\hline & & $\begin{array}{l}\text { Ödevlerini eksik ya da gelişigüzel } \\
\text { yapmak }\end{array}$ & 12 & 24.0 \\
\hline & & $\begin{array}{l}\text { Verilen yönergeler konusunda gereksiz } \\
\text { açiklamalar istemek }\end{array}$ & 12 & 24.0 \\
\hline & & $\begin{array}{r}\text { Türkçe ve İngilizce Bilen Öğretmen } \\
\text { Sayısı }\end{array}$ & 50 & 38.5 \\
\hline \multirow{2}{*}{ סُ } & \multirow{2}{*}{ Hiç } & $\begin{array}{l}\text { Öğretmene kafa tutmak ve saygısız } \\
\text { konuşmak }\end{array}$ & 56 & 81.2 \\
\hline & & $\begin{array}{l}\text { Sınıf dolabını izinsiz kullanmak ve } \\
\text { karıştırmak }\end{array}$ & 54 & 78.3 \\
\hline
\end{tabular}


A. Delen-M.H. Ercoskun $\quad$ Yabancı Uyruklu Öğrencilerin Bulunduğu...

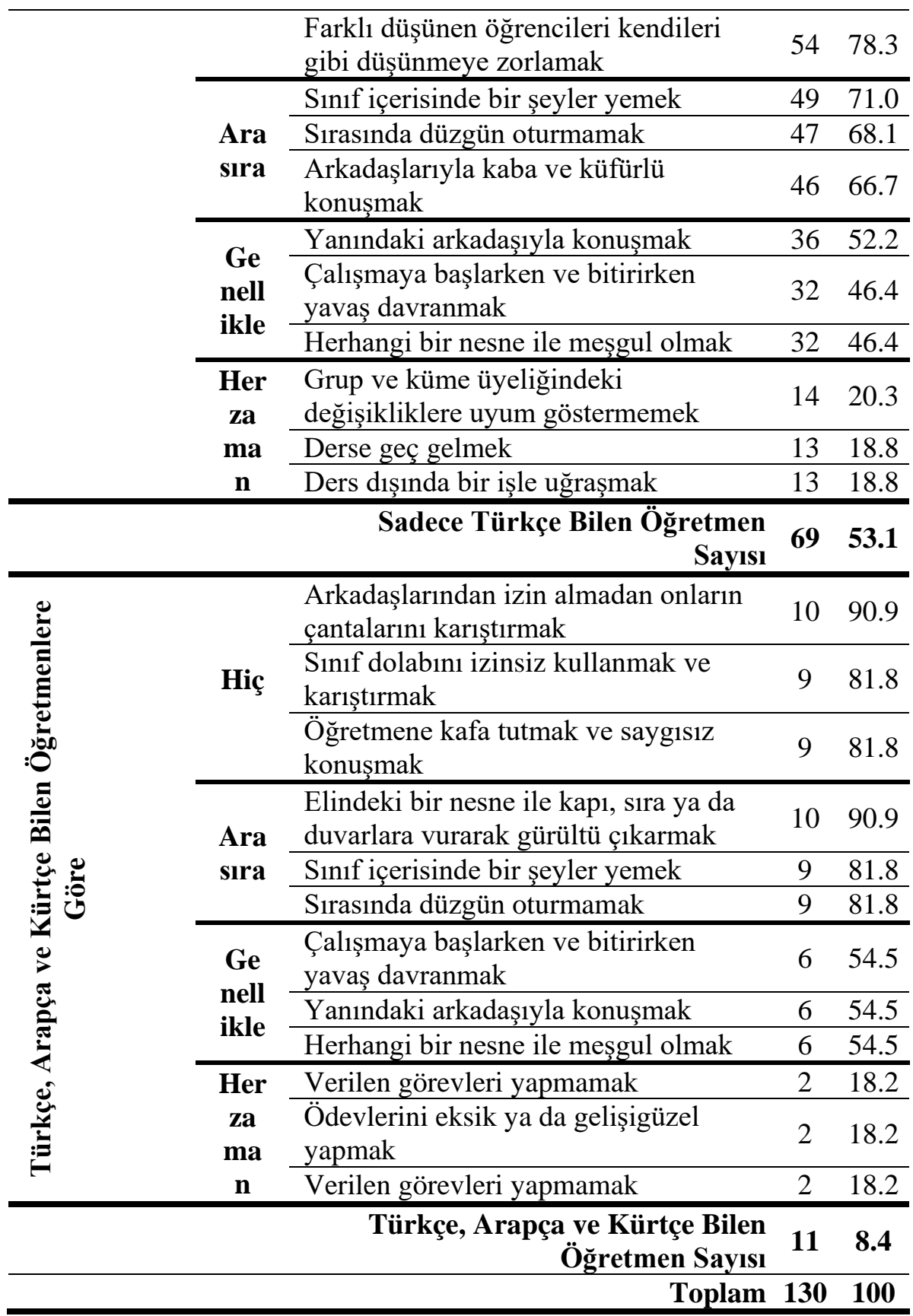

Tablo 9 incelendiğinde öğretmenlerin Türkçe, Arapça ve Kürtçe dillerini bilmesinin Türk öğrencilerde istenmeyen davranışların ortaya çıkmasını genel 
olarak azalttığı belirtilebilir. Anketteki 61 maddelik istenmeyen davranış türüne öğretmenlerden; sadece Türkçe bilen öğretmenlerin 21, Türkçe ve İngilizce bilen öğretmenlerin 20, Türkçe, Arapça ve Kürtçe bilen öğretmenlerin ise 59 maddesine "Her zaman" düzeyinde Türk öğrencilerde karşılaşmadıklarına dair yanıt vermişlerdir. Türk öğrencilerde "hırsızlık", "öğretmene kafa tutma ve saygısızlık", "sınıf dolabını ve arkadaşlarının çantasını izinsiz karıştırmak" gibi istenmeyen davranışların "Hiç" görülmediği ifade edilebilir. "Verilen görevleri yapmamak", "sınıf içerisinde bir şeyler yiyip-içmek", "okula geç gelmek" ve "herhangi bir nesne ile meşgul olmak" gibi istenmeyen davranışlar "Ara sıra" görülen istenmeyen davranışlarken, "birbirlerini şikâyet etmek", "yanındaki ile konuşmak", "arkadaşlarının ve öğretmeninin sözünü kesmek", "sınıf içi kurallara uymamak", "okula araç-gereçlerini eksik getirmek" ve "yönergeler hakkında gereksiz açıklamalar yapmak" "Genellikle" ve "Her zaman" Türk öğrencilerde görülen istenmeyen davranışlardır denilebilir. Tüm öğretmenler, Türk öğrencilerin "Genellikle" birbirlerini şikâyet ettiklerini, sıraları gelmeden arkadaşlarının ve öğretmenin sözünü keserek konuştuklarını ve birbirlerini şikâyet ettiklerini ileri sürmüşlerdir.

Tablo 10'a göre; öğretmenler tarafindan yabancı uyruklu öğrencilerin; hırsızlık yapmadıkları, arkadaşlarını kendileri gibi düşünmeye zorlamadıkları, öğretmene saygısızlık yapmadıkları, sınıf dolabını ve arkadaşlarının çantalarını karıştırmadıkları belirlenmiştir ve bu durumun öğretmenlerin bildikleri yabancı dillere göre farklılık göstermediği kanaatine varılmışır. Öğretmenlere göre; yabancı uyruklu öğrencilerin "Ara sıra" sergiledikleri istenmeyen davranışların; sınıf içerisinde bir şeyler yemek, yerinde düzgün oturmamak, ders araçgereçlerini düzgün kullanmama, sorumluluktan kaçma ve arkadaşlarından kopya çekme gibi istenmeyen davranışlar olduğu ve bu durumun öğretmenlerin bildikleri dillere göre farklılık göstermediği anlaşılmıştır. Yabancı uyruklu öğrencilerin "Genellikle" ders dışı bir şeyle uğraştıkları, sınıf kurallarına uymadıkları ve eksik ders araç-gereçleriyle okula geldikleri ifade edilmiştir. Öğretmenlere göre; bu öğrencilerin, Türkçe bilmediklerinden dolayı derste sıkıldıkları ve ders dışı şeylerle uğraştıkları kanaatine varılmıştır. Ancak öğretmenlerin Türkçe, Arapça ve Kürtçe dillerini bilmeleri, yabancı uyruklu öğrencilerde istenmeyen davranışların oluşmasını genel olarak azalttığı ifade edilebilir. Anketteki 61 maddelik istenmeyen davranış türüne öğretmenlerden; sadece Türkçe bilenlerin 6; Türkçe ve İngilizce bilenlerin 6; Türkçe, Arapça ve Kürtçe bilenlerin ise 60 maddesine; "Her zaman" düzeyinde yabancı uyruklu öğrencilerde istenmeyen davranışlara karşılaşmadıklarına yönelik yanıt verdikleri anlaşılmıştır. Başka bir deyişle istenmeyen davranışların ana nedenlerinden birisi olan dil ve iletişim sorunlarının olmadığı sınıflarda özellikle yabancı uyruklu öğrencilerin daha az istenmeyen davranış sergiledikleri ifade edilebilir. Bu araştırmanın yapıldı ğı yerdeki yabancı uyruklu öğrencilerin Suriye ve Irak uyruklu olmalarından dolayı, bu çocukların bildiği Arapça ve Kürtçe 


\section{A. Delen-M.H. Ercoskun $\quad$ Yabancı Uyruklu Öğrencilerin Bulunduğu...}

dillerini bilen öğretmenlerin sınıf yönetiminde fazla zorluk çekmedikleri ve istenmeyen davranışlara daha az rastladıkları belirtilebilir.

\section{SONUÇ, TARTIȘMA VE ÖNERILER}

Öğretmenlerin görüşlerine göre, Türk ve yabancı uyruklu öğrencilerin genel olarak; hırsızlık yapmadıkları, öğretmene karşı saygısızlık yapmadıkları, arkadaşlarının çantalarını ve sınıf dolabını izinsiz karıştırmadıkları, farklı düşünen öğrencileri kendileri gibi düşünmeye zorlamadıkları sonucuna varılmıştır. Öğretmenler; Türk ve yabancı uyruklu öğrencilerin genellikle; birbirlerini şikâyet ettiklerini, arkadaşlarının ve öğretmenin sözünü kestiklerini, birbirleriyle konuștuklarını, sınıf içi etkinliklerde aktif olmadıklarını ve isteksiz davrandıklarını, ders dışı işlerle ilgilendiklerini, ödevlerini rastgele yaptıklarını ve devamlı konuşarak diğer arkadaşlarını çalışmalarında rahatsız ettiklerini ileri sürmüşlerdir. Öğretmenler tarafından; yabancı uyruklu öğrencilerde görülen derste sıkılma, dikkat dağınıklığı ve arkadaşlarına karşı fiziksel şiddet uygulama gibi istenmeyen davranışların temel nedeninin, dil ve iletişim sorunlarından kaynaklandığı belirtilmiştir. Bu konu ile ilgili olarak; benzer şekilde Yiğit (2015), Taştan ve Çelik (2017) Suriyeli öğrencilerin dil ve iletişim problemleri yaşamalarının ve kültürel farklılıkların olmasının eğitimlerine ve akademik başarılarına engel olduğunu belirtmişlerdir. Kıroğlu, Kesten ve Elma (2010: 27), yabancı uyruklu öğrencilerin genel olarak dil ve iletişim sorunlarıyla beraber toplumsal, kültürel ve maddi anlamda pek çok sorunla karşılaştıklarını, bu öğrencilerde yalnız kalma, uyum sorunları, çekinme ve çeşitli psikolojik sıkıntıların görüldüğünü belirtmișlerdir. Balkar, Șahin ve Ișıklı Babahan (2016) Geçici Eğitim Merkezlerinde Suriyeli öğretmenlerin sınıf yönetimi ve disiplin konularında birtakım sorunlarla karşılaştıklarını saptamışlardır.

Türk öğrencilerde görülen istenmeyen davranışlara en çok; bilgisayar oyunları, TV dizileri vb. gibi medya ve kitle iletişim araçlarının olumsuz etkileri, kalabalık sınıflar, aile içi sorunlar, arkadaş çevresi ve ekonomik sorunlar gibi etkenlerin neden olduğu belirtilmiștir. Sonuçları bu çalıșmaya benzer olan araştırmalar vardır (Kayıkcı, 2013; Sadık, 2000; Türnüklü, 2001). Yabancı uyruklu öğrencilerde görülen istenmeyen davranışlara en çok; sosyal ve kültürel değişim/göç, aile içi sorunlar, dil ve iletişim sorunları, ekonomik nedenler, öğrencinin fiziksel ve sosyal gelişiminin uygun olmaması, öğrenme güçlüğü çekmesi, akademik yetersizlik gibi etkenlerin neden olduğu belirtilmiştir. Taştan ve Çelik (2017) Suriye ve Irak gibi savaşın hakim olduğu yerlerden Türkiye'ye gelen yabancı uyruklu çocukların, maddi yetersizliklerden, dil ve iletişim sorunlarından, kültürel farklılıklardan, ulaşım sorunlarından, bürokratik iş ve işlemlerin nasıl yürütüldüğünü bilmemelerinden ve geleceğe yönelik belirsizliklerden dolayı bir takım sorunlar yaşadıkları belirtmişlerdir. Benzer şekilde Şeker ve Sirkeci (2015) çalışmalarında, Suriyeli ailelerin, çocuklarının 
eğitimi için gereken hassasiyeti ve ilgiyi veremediklerini belirtmişlerdir. Yine Topsakal, Merey ve Keçe (2013), maddi sorunlar ve ailelerin bilinçsiz olmasından dolayı çocukların okul saatlerinde veya bu saatler dışında çalıştırıldıklarını belirtmişlerdir.

Cinsiyet açısından Türk ve yabancı uyruklu öğrencilerde istenmeyen davranışların gerçekleşme düzeylerinin farklı olmadığg görülmüsştür. Kadın ve erkek öğretmenlere göre; Türk ve yabancı uyruklu öğrencilerin genellikle, birbirleriyle konuştukları, birbirlerini şikâyet ettikleri, ders dışı şeylerle uğraştıkları, diğer arkadaşlarını rahatsız ettikleri, ödevlerini rastgele yaptıkları, birbirlerinin ve öğretmenin sözünü kestikleri, verilen yönergeler konusunda gereksiz açıklamalara ihtiyaç duydukları sonucuna varılmıştır. Yine cinsiyet açısından Türk ve yabancı uyruklu öğrencilerde görülen istenmeyen davranışların nedenlerinin de farklı olmadığı sonucuna varılmıştır.

Sinıflardaki yabancı uyruklu öğrenci sayısının artması Türk öğrencilerde istenmeyen davranışların gerçekleşme düzeyine biraz da olsa etki etmektedir. Düşük akademik düzeye sahip ve Türkçe bilmeyen yabancı uyruklu öğrenci sayısının sınıf içerisinde fazla olmasının hem kendileri hem de Türk öğrenciler açısından olumsuz sonuçlara neden olduğu söylenebilir. Çünkü sınıf öğretmeninin ders süresince yabancı uyruklu öğrencilere Türkçe öğretmek için uğraşması durumunda Türk öğrencilerin olumsuz etkilenebilecekleri, yabancı uyruklu öğrencilerle ilgilenmemesi halinde ise onların boş kalacaklarından dolayı istenmeyen davranışlar sergileyebilecekleri söylenebilir. Sınıflardaki yabancı uyruklu öğrenci sayısına göre yabancı uyruklu öğrencilerde istenmeyen davranışların gerçekleşme düzeyi ile ilgili olarak öğretmenler; sınıftaki yabancı uyruklu öğrenci sayısının 1-3 kişi olmasının istenmeyen davranışların gerçekleşmesine çok az; 4 ve daha fazla olmasının ise daha fazla etki ettiğini belirttikleri tespit edilmiştir. Bu nedenle istenmeyen davranışlarla baş etmek için eğitim ortamını düzenleyerek destekleyici hale getirmek ve gerekli planlamaları yapmak önemli bir adımdır (Emmer ve Stough, 2001).

Öğretmenlerin bildikleri yabancı dil sayısına göre, Türk ve yabancı uyruklu öğrencilerde istenmeyen davranışlara, Türkçe ile beraber Arapça ve Kürtçe dillerini bilen öğretmenlerin sınıflarında çok az rastlandığ 1 sonucuna varılmıştır. Araştırmanın yapıldığ 1 okullardaki yabancı uyruklu öğrenciler ve bunların ailelerinin; Suriye ve Irak'tan gelmelerinden dolayı Arapça, Kürtçe veya her iki dili de bildiklerinden dolayı bu öğrencilerin dillerini bilen, onların ailesiyle etkili iletişim kurabilen sınıf öğretmenlerinin istenmeyen davranışları büyük olasılıkla ortadan kaldırabileceği düşünülmektedir. Öğretmenler; yabancı uyruklu öğrencilerin dil ve iletişim sorunlarından ötürü derste sıkıldıklarını ve ders dışı şeylerle uğraştıklarını düşünmektedirler. Başka bir deyişle öğretmenler tarafından, istenmeyen davranışların ana nedenlerinden birisi olarak görülen dil 


\section{A. Delen-M.H. Ercoskun $\quad$ Yabancı Uyruklu Öğrencilerin Bulunduğu...}

ve iletişim problemlerinin olmadığ 1 sınıflarda istenmeyen davranışların azaldığ ifade edilebilir.

Yukarıda belirtilen bulgu ve sonuçlara göre şu öneriler ileri sürülebilir: Yabancı uyruklu öğrencilere yönelik olarak destekleme ve yetiştirme kursları açılmalı, amacına ulaşıncaya kadar bunlar sürdürülmelidir. Yabancı uyruklu öğrenciler Türk okullarındaki sınıflara alınmadan önce seviye belirleme sınavına alınmalıdır. Okulların altyapısı güçlü hale getirilmeli, derslik sayısı fazlalaştırılmalı ve sınıf yoğunluğu azaltılmalıdır. Yabancı uyruklu öğrencilere uyum programı hazırlanmalı, rehberlik ve psikolojik danışmanlık desteği sağlanmalıdır. Yabancı uyruklu ve Türk öğrenciler ortak sosyal, kültürel ve sportif etkinliklerle bir araya getirilerek kaynaştırılmalı, birbirleriyle iletişim kurmaları güçlendirilmelidir. Ara sınıflara mümkün oldukça az sayıda yabancı uyruklu öğrenci alınmalıdır. Öğretmenlere kaynaştırma eğitimi ile ilgili bilgilendirme yapılmalı, yabancı uyruklu öğrencilere yönelik farklı ve etkili eğitim yöntem ve tekniklerini kullanmaları için destekleyici eğitimler verilmeli ve sınıfinda yabancı uyruklu öğrenci olan ve sadece Türkçe bilen öğretmenlere yabanc1 uyruklu öğrencilerin bildiği dillere yönelik temel düzeyde dil eğitimi verilmelidir. Yabancı uyruklu çocukların, iletişim, ulaşım ve diğer toplumsal problemlerini gidermek için destek olunmalıdır. Sınıfında yabancı uyruklu öğrencisi bulunan öğretmenler mahalli veya merkezi hizmet içi eğitim kurs ve seminerlerine alınmalı, dönem başında ve dönem sonlarında zümre toplantılarına katarak yabancı uyruklu öğrencilerle ilgili elde ettikleri deneyimlerini karşılıklı paylaşmalarına firsat verilmelidir.

\section{KAYNAKÇA}

Balkar, Betül, Şahin, Sevilay ve Işıklı Babahan, Nur (2016). "Geçici eğitim merkezlerinde (GEM) görev yapan Suriyeli öğretmenlerin karşılaştıkları sorunlar”. Eğitimde Kuram ve Uygulama, 12(6), ss.1290-1310.

Burden, Paul R. (1995). Classroom management and discipline: Methods to facilitate cooperation and instruction. Longman Publishers, USA.

Cebeci, Betül (2016). İlköğretim kurumlarında öğrencilerin istenmeyen davranışlarına dair öğretmen tutumlarının çeşitli değişkenler açısından incelenmesi. Yayımlanmamış Yüksek Lisans Tezi. Sebahattin Zaim Üniversitesi Sosyal Bilimler Enstitüsü, İstanbul.

Emmer, Edmund T. ve Stough, Laura M. (2001). "Classroom management: a critical part of educational psychology, with implications for teacher education”. Educational Psychologist, 36(2), ss.103-112. 
Geiger, Brenda (2000). "Discipline and classroom management in $\mathrm{K}$ thru 8th grades”. Education, 121(2), ss.383-393.

Gottfredson, Gary D. \& Gottfredson, Denise C. (2001). "What schools do to prevent problem behavior and promote safe environtments". Journal of Educational and Psychological Consultation, 12(4), ss.313-344.

Guttmann, Joseph (1982). “Pupils', teachers', and parents' causal attributions for problem behavior at school”. Journal of Educational Research, 76(1), 14-21.

Karadağ, Engin ve Üney, Ahmet (2006). “İlköğretim Birinci Kademe Öğrencilerinin Sınıf İçi Olumsuz Davranışlarının Değerlendirilmesi”. Hasan Ali Yücel Eğitim Fakültesi Dergisi, 1, ss.119-134.

Karasar, Niyazi (2013). Bilimsel Araştırma Yöntemi. (25. Basım). Nobel Yayınları, Ankara.

Kayıkcı, Merve (2013). "İlkokullarda sınıf öğretmenlerinin sınıf içerisinde karşılaştığı istenmeyen davranışlar ve bu davranışlar ile baş etme yolları (Ödül ve ceza yöntemi)”. Yayımlanmamış Yüksek Lisans Tezi. Hasan Kalyoncu Üniversitesi Sosyal Bilimler Enstitüsü, İstanbul.

Keyik, Hatice (2014). “İlkokul 1.sınıf öğretmenlerinin öğrencilerin istenmeyen baş etmede kullandıkları sınıf yönetimi stratejileri”. Yayımlanmamış Yüksek Lisans Tezi. Mehmet Akif Ersoy Üniversitesi Eğitim Bilimleri Enstitüsü, Burdur.

Kılıçoğlu, Cazibe (2015). "Sınıf içerisinde istenmeyen davranışlara karşı öğretmenlerin baş edebilme yöntem ve teknikleri”. Yayımlanmamış Yüksek Lisans Tezi. Toros Üniversitesi Sosyal Bilimler Enstitüsü, Mersin.

Kıroğlu, Kasım- Kesten, Alper ve Elma, Cevat (2010). “Türkiye'de Öğrenim Gören Yabancı Uyruklu Lisans Öğrencilerinin Sosyo-Kültürel ve Ekonomik Sorunları”. Mersin Üniversitesi Eğitim Fakültesi Dergisi, 6(2), ss. 26-39.

Lake, Celinda C. ve Harper, Pat Callbeck (2008). Kamuoyu Araştırmaları. (N. Güz, Çev.). Eğitim Akademi Yayınları, Ankara.

Sadık, Fatma (2000). İlköğretim I. Aşama Sınıf Öğretmenlerinin Sınıfta Gözlemledikleri Problem Davranışlar. Yayımlanmış Yüksek Lisans Tezi. Çukurova Üniversitesi Sosyal Bilimler Enstitüsü, Adana. 


\section{A. Delen-M.H. Ercoskun $\quad$ Yabancı Uyruklu Öğrencilerin Bulunduğu...}

Sağlam, Serdar (2006). “Türkiye'de İç Göç Olgusu Ve Kentleşme”. Türkiyat Araştırmaları, 5, ss.33-44.

Şeker, Betül Dilara ve Sirkeci, İbrahim. (2015). "Challenges For Refugee Children At School In Eastern Turkey”. Economics and Sociology, 8(4), ss.122-133. Doi: 10.14254/2071-789X.2015/8-4/9.

Taştan, Coşkun ve Çelik, Zafer (2017). Türkiye'de Suriyeli Çocukların Eğitimi: Güçlükler ve Öneriler. Eğitim-Bir-Sen Stratejik Araştırmalar Merkezi, Ankara.

Topsakal, Cem, Merey, Zihni ve Keçe, Murat (2013). “Göçle Gelen Ailelerin Çocuklarının Eğitim Öğrenim Hakkı ve Sorunları Üzerine Nitel Bir Çalışma". Uluslararası Sosyal Araştırmalar Dergisi, 6(27), ss.546-560.

Türnüklü, Abbas (2001). “Türk ve İngiliz ilköğretim öğretmenlerinin sınıf içi davranış yönetim stratejilerinin karşılaştırılması”. Eğitim Yönetimi Dergisi, (23), ss.449-466.

Ünüvar, Gizem Cengiz (2014). “İlkokul öğrencilerinin sınıfta istenmeyen davranışlar gösterme sıklığının ebeveyn tutumuyla ilişkisi”. Yayımlanmamış Yüksek Lisans Tezi. Celal Bayar Üniversitesi Sosyal Bilimler Enstitüsü, Manisa.

Yiğit, Tuğba (2015). Uygulamalar ve sorunlar bağlamında Türkiye'de sığınmacı çocukların eğitimi (Kırşehir ve Nevşehir örneği). Yayımlanmamış Yüksek Lisans Tezi. Ahi Evran Üniversitesi Sosyal Bilimler Enstitüsü, Kırşehir. 